\title{
Radical budget analysis in a suburban European site during the MEGAPOLI summer field campaign
}

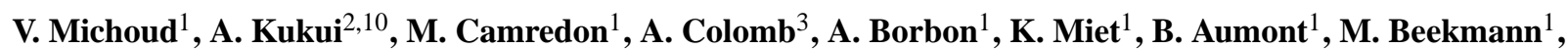 \\ R. Durand-Jolibois ${ }^{1}$, S. Perrier ${ }^{1,4}$, P. Zapf ${ }^{1}$, G. Siour ${ }^{1}$, W. Ait-Helal ${ }^{1,5,6}$, N. Locoge ${ }^{5,6}$, S. Sauvage ${ }^{5,6}$, C. Afif ${ }^{1,7}$, \\ V. Gros ${ }^{8}$, M. Furger ${ }^{9}$, G. Ancellet ${ }^{2}$, and J. F. Doussin ${ }^{1}$ \\ ${ }^{1}$ LISA, UMR-CNRS 7583, Université Paris Est Créteil (UPEC), Université Paris Diderot (UPD), Institut Pierre Simon \\ Laplace (IPSL), Créteil, France \\ ${ }^{2}$ LATMOS, UMR-CNRS 8190, Université de Versailles Saint Quentin, Université Pierre et Marie Curie, Guyancourt, France \\ ${ }^{3}$ LaMP, UMR-CNRS 6016, Clermont Université, Université Blaise Pascal, Aubière, France \\ ${ }^{4}$ ISA, UMR-CNRS 5280, Université Lyon 1, ENS-Lyon, Villeurbanne, France \\ ${ }^{5}$ Université Lille Nord de France, Lille, France \\ ${ }^{6}$ Department of Chemistry and Environment, Ecole des Mines de Douai, Douai, France \\ ${ }^{7}$ Centre d'Analyses et de Recherche, Faculty of sciences, Université Saint Joseph, Beirut, Lebanon \\ ${ }^{8}$ LSCE, Université de Versailles Saint Quentin en Yvelines, CEA, CNRS, Gif sur Yvette, France \\ ${ }^{9}$ Laboratory of Atmospheric Chemistry, Paul Scherrer Institut, Villigen, Switzerland \\ ${ }^{10}$ LPC2E, UMR-CNRS 6115, Orléans, France
}

Correspondence to: J. F. Doussin (jean-francois.doussin@lisa.u-pec.fr)

Received: 14 June 2012 - Published in Atmos. Chem. Phys. Discuss.: 26 June 2012

Revised: 8 October 2012 - Accepted: 12 November 2012 - Published: 17 December 2012

\begin{abstract}
Chemical Ionisation Mass Spectrometer measurements of hydroxyl radical $(\mathrm{OH})$ and the sum of hydroperoxy and organic peroxy $\left(\mathrm{HO}_{2}+\mathrm{RO}_{2}\right)$ radicals were conducted during the MEGAPOLI summer field campaign at the SIRTA observatory near Paris, France, in July 2009. OH and $\left(\mathrm{HO}_{2}+\mathrm{RO}_{2}\right)$ showed a typical diurnal variation with averaged daytime maxima values around $5 \times 10^{6}$ and $1.2 \times 10^{8}$ molecule $\mathrm{cm}^{-3}$, respectively. Simultaneously, a large number of ancillary measurements, such as $\mathrm{NO}_{\mathrm{x}}, \mathrm{O}_{3}, \mathrm{HONO}$, $\mathrm{HCHO}$ and other VOCs were also conducted. These data provide an opportunity to assess our understanding of the radical chemistry in a suburban environment by comparing the radical observations to calculations. First, $\mathrm{OH}$ mixing ratios were estimated by a simple Photo Stationary State (PSS) calculation. PSS calculations overestimate the $\mathrm{OH}$ mixing ratio by $50 \%$, especially at $\mathrm{NO}_{\mathrm{x}}$ mixing ratios lower than $10 \mathrm{ppb}$, suggesting that some loss processes were missing in the calculation at low $\mathrm{NO}_{\mathrm{x}}$. Then, a photochemical box model simulation based on the Master Chemical Mechanism (MCM) and constrained by ancillary measurements was run to calculate radical concentrations. Three different modelling procedures
\end{abstract}

were tested, varying the way the unconstrained secondary species were estimated, to cope with the unavoidable lack of their measurements. They led to significant differences in simulated radical concentrations. $\mathrm{OH}$ and $\left(\mathrm{HO}_{2}+\mathrm{RO}_{2}\right)$ concentrations estimated by two selected model version were compared with measurements. These versions of the model were chosen because they lead, respectively, to the higher and lower simulated radical concentrations and are thus the two extremes versions. The box model showed better results than PSS calculations, with a slight overestimation of $12 \%$ and $5 \%$, for $\mathrm{OH}$ and $\left(\mathrm{HO}_{2}+\mathrm{RO}_{2}\right)$ respectively, in average for the reference model, and an overestimation of approximately $20 \%$ for $\mathrm{OH}$ and an underestimation for $\left(\mathrm{HO}_{2}+\mathrm{RO}_{2}\right)$ for the other selected model version. Thus, we can conclude from our study that $\mathrm{OH}$ and $\left(\mathrm{HO}_{2}+\mathrm{RO}_{2}\right)$ radical levels agree on average with observations within the uncertainty range. Finally, an analysis of the radical budget, on a daily basis (06:00-18:00 UTC), indicates that HONO photolysis $(\sim 35 \%), \mathrm{O}_{3}$ photolysis $(\sim 23 \%)$, and aldehydes and ketones photolysis ( $\sim 16 \%$ for formaldehyde and $18 \%$ for others $)$ are the main radical initiation pathways. According to the MCM 
modelling, the reactions of $\mathrm{RO}_{2}$ with $\mathrm{NO}_{2}(\sim 19 \%)$, leading mainly to PAN formation, is a significant termination pathway in addition to the main net loss via reaction of $\mathrm{OH}$ with $\mathrm{NO}_{2}(\sim 50 \%)$.

\section{Introduction}

The hydroxyl $(\mathrm{OH})$ radical is the main oxidant of the troposphere during daytime (Levy, 1972). It plays an important role in the oxidation of many atmospheric species, leading to the formation of secondary pollutants such as ozone $\left(\mathrm{O}_{3}\right)$ and Secondary Organic Aerosols (SOA) through a radical cycle where $\mathrm{OH}$ is regenerated. Indeed, $\mathrm{OH}$ reaction with organic compounds leads to peroxy radicals $\left(\mathrm{RO}_{2}\right)$ formation. These peroxy radicals react with $\mathrm{NO}$ to form $\mathrm{NO}_{2}$ and alkoxy radicals (RO). RO next evolves to the formation of hydroperoxy radical $\left(\mathrm{HO}_{2}\right)$ and secondary organic compounds. Finally, $\mathrm{HO}_{2}$ reacts with $\mathrm{NO}$ to form $\mathrm{OH}$ and $\mathrm{NO}_{2}$. The radical interconversion cycles effectively link the $\mathrm{OH}, \mathrm{HO}_{2}$ and $\mathrm{RO}_{2}$ radicals chemistry and lead to the formation of ozone, as a by-product of $\mathrm{NO}$ to $\mathrm{NO}_{2}$ conversion followed by $\mathrm{NO}_{2}$ photolysis (Finlayson-Pitts and Pitts, 2000).

A major source of radicals in both clean and polluted atmospheres is the ozone photolysis followed by a rapid reaction between $\mathrm{O}\left({ }^{1} \mathrm{D}\right)$ and water vapour. In polluted areas, other radical photolytic sources can also be important for radicals, such as nitrous acid (HONO) (Aumont et al., 2003; Acker et al., 2006; Kleffman, 2007) and formaldehyde $(\mathrm{HCHO})$ or other aldehydes photolysis (Emmerson et al., 2005b). Other non photolytic sources can be important for radical production, such as ozone reactions with alkenes, especially during the night in summer or throughout the day during winter (Donahue et al., 1998; Bey et al., 2001; Kanaya et al., 2007), or reactions of $\mathrm{NO}_{3}$ radical with unsaturated VOC which lead to peroxy radicals during the night (Salisbury et al., 2001; Geyer et al., 2003). In spite of their key role in the atmospheric oxidizing cycles, radical measurements are not always present in field campaign datasets as their great reactivity and low atmospheric concentration make their monitoring difficult.

During the past decades several campaigns including radical measurements were carried out in various environments (Heard and Pilling, 2003). Most of these experiments took place in rural or remote environments (Mount and Williams, 1997; Eisele et al., 1997; Carslaw et al., 1999b, 2001; Creasey et al., 2001; Tan et al., 2001; Kanaya et al., 2001; Creasey et al., 2002; Holland et al., 2003; Mihelcic et al., 2003; Smith et al., 2006; Ren et al., 2006; Hofzumahaus et al., 2009) but some campaigns with radical measurements were also conducted in urban or sub-urban environments (George et al., 1999; Ren et al., 2003b; Emmerson et al., 2005a, 2007; Kanaya et al., 2007; Dusanter et al., 2009).
The common goal of all these studies was to assess our understanding of the previously described oxidizing cycles under various environmental conditions. The relative contribution of the initiation reaction, the efficiency of the recycling pathways and the importance of various sinks were investigated by comparing the radical measurements with results of simulation using different photochemical models constrained with observations of longer-lived species and environmental parameters. An agreement between the measurements and simulations suggests generally that the radical chemistry is adequately described by a model. At the same time, taking apart possible measurement errors, discrepancies between measurements and model may indicate that significant initiation, termination or recycling processes are not properly accounted in the model and that probably important constraints are missing. Such situation is likely to be encountered in complex environments where radical chemistry should be described with accounting for a detailed mechanism including large number of different species (VOCs, OVOCs, etc).

Applied in both rural and urban environments, this approach has led to various outcomes. While the agreement between measured and modelled $\mathrm{HO}_{\mathrm{x}}$ is generally good in urban environments (Martinez et al., 2003; Ren et al., 2003a; Shirley et al., 2006; Kanaya et al., 2007), some studies have shown underestimation of $\mathrm{OH}$ measurements by models in forested areas at low $\mathrm{NO}_{\mathrm{x}}$ (Tan et al., 2001; Carslaw et al., 2001; Hofzumahaus et al., 2009), suggesting unknown non NO-dependent $\mathrm{OH}$ regeneration pathways. Indeed, Hofzumahaus et al. (2009) have found strong underestimation by a factor of 3 to 5 of $\mathrm{OH}$ concentrations calculated using the Regional Atmospheric Chemical Mechanism (RACM) (Stockwell et al., 1997), whereas good agreement was found for $\mathrm{HO}_{2}$ concentrations. This difference for $\mathrm{OH}$ can neither be explained by uncertainties nor by measurement interferences. The authors proposed two reactions to explain it, $\mathrm{RO}_{2}+\mathrm{X} \rightarrow \mathrm{HO}_{2}$ and $\mathrm{HO}_{2}+\mathrm{X} \rightarrow \mathrm{OH}$, both of similar rates, as in the case of the corresponding NO reactions. The addition of these reactions with a concentration of $0.85 \mathrm{ppb}$ equivalent $\mathrm{NO}$ for $\mathrm{X}$ allows the model to reproduce well $\mathrm{OH}$ and $\mathrm{HO}_{2}$ concentrations. However, considering the $\mathrm{RO}_{2}$ interference in the $\mathrm{HO}_{2}$ detection channel of the LIF-instrument (Fuchs et al., 2011), Lu et al. (2012) have reevaluated the dataset and extended the model analysis. They concluded that the need of an additional $\mathrm{HO}_{2}$ to $\mathrm{OH}$ recycling process persists but that the need of an unknown recycling $\mathrm{RO}_{2}$ to $\mathrm{HO}_{2}$ to match observed $\mathrm{HO}_{2}$ has diminished. During Intercontinental Chemical Transport Experiment-A (INTEX-A), Ren et al. (2008) compared the $\mathrm{HO}_{\mathrm{x}}$ concentrations obtained with a model developed at the NASA Langley Research Center with airborne measurements. For most of the troposphere, the model agrees well with $\mathrm{OH}$ and $\mathrm{HO}_{2}$ observations, with averaged observed-to-model ratios being respectively 0.95 and 1.28 . Nonetheless, underestimation for $\mathrm{OH}$ correlated with isoprene levels was found in the planetary boundary layer in forested environments: the observed 
to model ratio increased from 1 to 1.5 when isoprene rose from less than $10 \mathrm{ppt}$ to $500 \mathrm{ppt}$ and up to 5 when isoprene exceeded 500 ppt.

On the contrary, many studies in remote or rural environments showed an overestimation of simulated $\mathrm{OH}$ concentrations at low $\mathrm{NO}_{\mathrm{x}}$ and better agreement at high $\mathrm{NO}_{\mathrm{x}}$ (Mount and Williams, 1997; Carslaw et al., 1999a; Mihelcic et al., 2003). Indeed, Mihelcic et al. (2003) found that at high $\mathrm{NO}_{\mathrm{x}}$, during BERLIOZ campaign at about $50 \mathrm{~km}$ in the North West of the city-center of Berlin, $\mathrm{OH}$ is well reproduced by the MCM with a slight overestimation (10-30\%), whereas at low $\mathrm{NO}_{\mathrm{x}} \mathrm{OH}$ is overpredicted by a factor comprised between 1.5 and 1.7 and $\mathrm{RO}_{2}$ is overestimated by a factor of 2 or more on some days. This general model radical overestimation at low $\mathrm{NO}_{\mathrm{x}}$ suggests that some radical sinks were missing in the model. Using a MCM constrained box model during the EASE97 campaign which took place on the remote west coast of Ireland, Carslaw et al. (2002) have observed an overestimation of both $\mathrm{OH}$ and $\mathrm{HO}_{2}$ by their model, while a good agreement is found for $\mathrm{RO}_{\mathrm{x}}$ over a wide range of conditions. The author improved the model-measurements discrepancies by adding $\mathrm{HO}_{2}$ loss on aerosol surfaces increasing the mass accommodation coefficient of $\mathrm{HO}_{2}$ to 1 and constraining $\mathrm{HO}_{2}$ in the model to measured values. However, these changes could not explain all the differences between model and measurements. According to these authors, these discrepancies occurred because the chemical composition of the air mass was not fully characterized. During the NAMBLEX campaign which was conducted at the same site as EASE97, Sommariva et al. (2006) found good agreement between measured and modelled $\mathrm{OH}$ concentrations using MCM, within $25 \%$. The model generally overestimated $\mathrm{HO}_{2}$ concentrations by about a factor of 2 or more. Nevertheless, better agreements are found for $\mathrm{HO}_{2}$ concentrations when adding both halogen monoxides chemistry and uptake of $\mathrm{HO}_{2}$ on sea-salt particles. Using Regional Atmospheric Chemical Mechanism (RACM), Dusanter et al. (2009) noted that his model consistently overestimated the $\mathrm{OH}$ concentrations measured during the Mexico City Metropolitan Area (MCMA) field campaign, when dicarbonyls were not constrained. The authors have also observed an underestimation of $\mathrm{HO}_{\mathrm{x}}$ during morning hours. These discrepancies increase with higher benzene and toluene concentrations and thus could be explained by a missing source linked to the poorly characterized aromatics oxidation mechanism under high $\mathrm{NO}_{\mathrm{x}}$ conditions in the model. A recent study comparing OH measurements from two different methods: a traditional FAGE and a new chemical removal method, has highlighted that some discrepancies between modelled and measured $\mathrm{OH}$ concentrations may come from error in $\mathrm{OH}$ measurements (Mao et al., 2012). Indeed, these authors found that the two $\mathrm{OH}$ measurements, performed in a forested site, give different results, the new method giving on average $40-50 \%$ of the $\mathrm{OH}$ traditional FAGE measurements. Furthermore, $\mathrm{OH}$ concentrations measured by the new method agree with mod- elled $\mathrm{OH}$ concentrations, using RACM simulation, while $\mathrm{OH}$ concentrations measured by traditional FAGE largely overestimate simulated $\mathrm{OH}$ concentrations. The authors explain the difference in $\mathrm{OH}$ concentrations measured by the two techniques from an internal $\mathrm{OH}$ formation causing interferences in the traditional FAGE technique.

Results from all these studies are still far from leading to a clear picture of the chemical mechanisms that are missing in the models. The uncertainties concern all steps of the radical oxidizing cycle, i.e. initiation, propagation and termination processes which are missing or not well enough estimated in the chemical mechanisms. The present work aims at adding some insight in radical atmospheric chemistry and analysing the radical cycles leading to the oxidation of atmospheric species in the suburban region of Paris Megacity. In the frame of MEGAPOLI (Megacities: Emissions, urban, regional and Global Atmospheric POLlution and climate effects, and Integrated tools for assessment and mitigation) project, a radical closure experiment was performed in the Paris region for the first time. Our study is mainly based on the comparison between observed and calculated radical concentrations as well as on a radical budget analysis using both a simple Photo Stationary State calculation (PSS) and a box model containing the Master Chemical Mechanism (MCM) and constrained with all the species and the parameters measured during MEGAPOLI ( $\mathrm{RH}$, temperature, pressure, boundary layer high, $J\left(\mathrm{O}^{1} \mathrm{D}\right), J\left(\mathrm{NO}_{2}\right), J(\mathrm{HONO})$, $\mathrm{NO}, \mathrm{NO}_{2}, \mathrm{O}_{3}, \mathrm{CO}, \mathrm{CH}_{4}, \mathrm{CO}_{2}, \mathrm{HCHO}, \mathrm{HONO}, \mathrm{PAN}$ and 32 VOC). Furthermore, during this study several modelling procedures have been tested in order to investigate the impact on radical estimation of the way the unconstrained secondary species are calculated.

\section{The MEGAPOLI experiment}

\subsection{The SIRTA suburban observatory}

The MEGAPOLI summer campaign took place between the 1 and the 31 July 2009 at several ground sites. This study is built on data collected at the SIRTA ("Site Instrumental de Recherche par Télédétection Atmosphérique") observatory (Haeffelin et al., 2005; Pietras et al., 2007). The SIRTA is a French national atmospheric observatory dedicated to cloud and aerosol research and is located at Palaiseau in "Ecole Polytechnique" area $\left(48.718^{\circ} \mathrm{N}, 2.207^{\circ} \mathrm{E}\right), 14 \mathrm{~km}$ south-west of Paris (France) in a semi-urban environment (Freutel et al., 2012). This site is downwind of Paris under anticyclonic conditions and receives oceanic air masses from west of France the rest of the time (Freutel et al., 2012). The choice of this site was motivated by a possibility to compare the radical chemistry under these different conditions. 


\section{$2.2 \mathrm{OH}$ and $\left(\mathrm{HO}_{2}+\mathrm{RO}_{2}\right)$ measurements}

The radicals $\mathrm{OH}$, the sum of hydroperoxy and organic peroxy radicals $\left(\mathrm{HO}_{2}+\mathrm{RO}_{2}\right)$ and sulfuric acid (not presented here) have been measured using chemical ionisation mass spectrometry (CIMS) (Eisele and Tanner, 1991; Tanner et al., 1997; Berresheim et al., 2000). Detailed description of the instrument has been presented elsewhere (Kukui et al., 2008). Here we briefly present the measurement technique and essential details about the setup and performance of the system during the MEGAPOLI campaign.

The $\mathrm{OH}$ radical is measured by converting sampled $\mathrm{OH}$ radicals into $\mathrm{H}_{2} \mathrm{SO}_{4}$ by addition of $\mathrm{SO}_{2}$ in a chemical conversion reactor (CCR) in the presence of water vapor and oxygen (Eisele and Tanner, 1991; Tanner et al., 1997; Berresheim et al., 2000). $\mathrm{H}_{2} \mathrm{SO}_{4}$ is detected by using mass spectrometry as $\mathrm{HSO}_{4}^{-}$ion is produced by chemical ionisation with $\mathrm{NO}_{3}^{-}$in an ion-molecule reactor following the CCR. To account for the contribution of atmospheric sulfuric acid the chemical conversion is performed using isotopically labelled ${ }^{34} \mathrm{SO}_{2}$ leading to the formation of $\mathrm{H}_{2}^{34} \mathrm{SO}_{4}$. The concentration of $\left(\mathrm{HO}_{2}+\mathrm{RO}_{2}\right)$ is measured by converting them into $\mathrm{OH}$ radicals via reactions with NO (Reiner et al., 1997), hereafter converted into sulfuric acid. The chemical conversion is terminated by addition of $\mathrm{NO}_{2}$, used as a radical scavenger, into the CCR (Kukui et al., 2008).

During the MEGAPOLI measurements the instrument was installed in a container with the CCR protruding through an interface cap covered with a Teflon sheet and fixed on the roof of the container. Ambient air is sampled into the CCR at a flow rate of $13 \mathrm{~L} \mathrm{~min}{ }^{-1}$ through a sampling aperture $(3 \mathrm{~mm}$ diameter) placed $50 \mathrm{~cm}$ above the roof (i.e. about $4 \mathrm{~m}$ above the ground) creating turbulent flow conditions in the reactor to minimise possible wind speed influence and ensure fast mixing of reactants. The CCR was similar to the one described in Kukui et al. (2008) except that the modified reactor is made of stainless steel and its exit tube is used as one of the electrodes forming ion trajectories in an ion-molecule reactor. The ion-molecule reactor has also been modified to allow addition of a "sheath" flow (Tanner et al., 1997) resulting in a significant reduction of the background signal.

Accounting for the calibration uncertainties and measurement precision, the overall $2 \sigma$ uncertainty of the $10 \mathrm{~min}$ averaged measurements of $\mathrm{OH}$ and $\left(\mathrm{HO}_{2}+\mathrm{RO}_{2}\right)$ is estimated to be $35 \%$ and $45 \%$, respectively. The detection limit of $8 \times 10^{5}$ molecule $\mathrm{cm}^{-3}$ for one $2 \mathrm{~min} \mathrm{OH}$ point was calculated from the signal statistics in background mode at a signal to noise ratio of 3. More detailed descriptions of the different measurement modes, the instrument calibration, the estimation of measurement precision and the data correction can be found in the Supplement S1.

\subsection{Photolysis frequencies measurements}

During the MEGAPOLI summer campaign, measurements of $J\left(\mathrm{NO}_{2}\right)$ and $J\left(\mathrm{O}^{1} \mathrm{D}\right)$ were performed using two filterradiometers and measurements of $J(\mathrm{HONO})$ using a spectroradiometer (LI-1800). The $J\left(\mathrm{NO}_{2}\right)$ filterradiometer was installed at the top of a $9 \mathrm{~m}$ mast. It was calibrated at the "Institut für Energie und Klimaforschung" at the Forschungszentrum Jülich GmbH in January 2011. Accounting for the calibration uncertainties and measurement precision, the $2 \sigma$ uncertainty of the $J\left(\mathrm{NO}_{2}\right)$ measurements is estimated to be $20 \%$.

The $J\left(\mathrm{O}^{1} \mathrm{D}\right)$ filterradiometer was installed on the same container roof as the CIMS inlet. The two filterradiometers were at a distance of about $10 \mathrm{~m}$. The $J\left(\mathrm{O}^{1} \mathrm{D}\right)$ filterradiometer can not be calibrated. Thus, we compared its measurements with $J\left(\mathrm{O}^{1} \mathrm{D}\right)$ calculated using the Tropospheric Ultraviolet and Visible (TUV version 5.0) (Madronich et al., 1998; McKenzie et al., 2007) radiation model for clear sky days (http://cprm.acd.ucar.edu/Models/TUV/). The Ozone Column used in these calculations came from data measured in Paris center in a station of the "Système d' Analyse par Observation Zénithale" (SAOZ) network (http://saoz.obs.uvsq. fr/saoz/). With this calculation the best fit between $J\left(\mathrm{NO}_{2}\right)$ calculated and measured was found for a surface albedo of 0.1 . Since the surface albedo is supposed to be smaller in the UV-B (Webb et al., 2000), we used a surface albedo of 0.05 for $J\left(\mathrm{O}^{1} \mathrm{D}\right)$ calculation (representative of an albedo in UV-B for a mix surface of grass (0.02) and Tarmac (0.08) (Webb et al., 2000)). With the above assumption about the surface albedo, a good correlation $\left(R^{2}>0.99\right)$ found between the calculated and measured $J\left(\mathrm{O}^{1} \mathrm{D}\right)$ for two clear sky days allows a reasonable estimation of the filterradiometer response factor. However, accounting for the calculation and the measurement uncertainties, the $J\left(\mathrm{O}^{1} \mathrm{D}\right)$ measurement uncertainty is estimated to be $20 \%$.

The spectroradiometer (LI-1800), that uses a manual shadower technique to estimate the direct and diffuse radiation (Cotte, 1995), was deployed in order to calculate other photolysis frequencies. This instrument was installed near the ground in the middle of a field, to avoid any effect of building shadows, and was about $20 \mathrm{~m}$ away from the two filterradiometers. The LI-1800 spectroradiometer results were scaled with the calibrated data of the $J\left(\mathrm{NO}_{2}\right)$ filterradiometer. Only the nitrous acid photolysis frequency $(J(\mathrm{HONO}))$ was measured with this spectroradiometer, uncertainties at lower wavelength being too large. Accounting for the combined uncertainties of LI-1800 and $J\left(\mathrm{NO}_{2}\right)$ measurements the $J(\mathrm{HONO})$ measurement uncertainty is estimated to be $25 \%$.

\subsection{Stable species measurements}

During the campaign, a wide variety of trace gases was measured ( $\mathrm{NO}, \mathrm{NO}_{2}, \mathrm{O}_{3}, \mathrm{CO}, \mathrm{HONO}, \mathrm{PAN}, \mathrm{HCHO}$, other aldehydes and ketones, and NMHC $\left(\mathrm{C}_{4}-\mathrm{C}_{16}\right)$, listed in Table 1$)$. 
NO was measured by a commercial analyser model AC31M (Environnement S.A.) using ozone chemiluminescence. The NO analyser was weekly calibrated using a standard $200 \mathrm{ppb}$ NO/Air mixture. Furthermore, multipoint calibrations $(0-40 \mathrm{ppb})$, using the same gas cylinder and a dilution system, were carried out before and after the campaign. $\mathrm{NO}_{2}$ was measured by a commercial analyser $\mathrm{NO}_{\mathrm{x}} \mathrm{TO}_{\mathrm{y}}$ (Metair) using luminol chemiluminescence as described in details by Hasel et al. (2005). This analyser was calibrated twice, before and after the campaign, using a cylinder containing $200 \mathrm{ppb} \mathrm{NO} /$ Air mixture and a dilution system.

Ozone was measured with an analyser model 49C (Thermo Environmental) using UV absorption. This instrument was calibrated before the campaign using a quantified ozone source (ANSYCO).

$\mathrm{CO}$ was measured by Gas Chromatography with Reduction Gas Detection. Detailed description of this technique is given in Gros et al. (1999).

PAN (PeroxyAcetyl Nitrate) was measured by Gas Chromatography with Electron Capture Detection (GC-ECD). The calibration of this instrument was performed, after the campaign, in a smog chamber (Wang et al., 2011) in which laboratory-synthesised PAN (Nielsen et al., 1982) was introduced and simultaneously measured by the GC-ECD and a FTIR (Fourier Transform Infrared spectrometer) instrument.

Nitrous acid (HONO) was measured by a wet chemical derivatization technique with sulphanilamide and $\mathrm{N}$-ethylene diamine as derivating agent and a phosphate buffer at $\mathrm{pH} 7$ as trapping solution. The detection of the azo-dye formed was made by a High Performance Liquid Chromatography (HPLC) with detection by visible absorption at $540 \mathrm{~nm}$. The instrument for nitrous acid measurement has been described in detail by Afif et al. (2012). This instrument was calibrated before and after the campaign using nitrite liquid solutions at different concentrations.

The formaldehyde (HCHO) and other aldehydes and ketones, representing 20 oxygenated species, were trapped on DNPH cartridges with a $3 \mathrm{~h}$ time resolution. The analysis of these cartridges was made by HPLC using the technique described by Detournay et al. (2011). The VOC measurements were made by two different techniques. A GC-FID, AirmoVOC from Chromatotec, was deployed to measure VOCs from $\mathrm{C}_{3}$ to $\mathrm{C}_{9}$. During the MEGAPOLI campaign this technique allowed measurements of 7 species from $C_{4}$ to $C_{6}$ including isoprene. This instrument was calibrated weekly using cylinders containing known mixtures of different VOCs. In addition, samples collected every three hours on Charcoal cartridges and analysed later by a GC-FID (Detournay et al., 2011) enabled measurement of 20 VOCs from $C_{7}$ to $\mathrm{C}_{16}$. More details on VOC measurements can be found in Ait-Helal et al. (2012).

\section{Model description}

\subsection{Simple quasi Photo Stationary State (PSS) approach}

The SIRTA site is located in a semi-urban area, where $\mathrm{NO}_{\mathrm{x}}$ concentrations reach up to some tenths of ppb. This site is thus dominated by intermediate or high $\mathrm{NO}_{\mathrm{x}}$ conditions. Under high $\mathrm{NO}_{\mathrm{x}}$ conditions the $\mathrm{OH}$ radical budget can be largely simplified by assuming that the loss of the sum of the radicals is governed by reaction of $\mathrm{OH}$ with $\mathrm{NO}$ and $\mathrm{NO}_{2}$. To determine whether or not the radical chemistry in Palaiseau during MEGAPOLI is governed by high $\mathrm{NO}_{\mathrm{x}}$ conditions, $\mathrm{OH}$ concentrations were estimated using simple Photo Stationary State (PSS) calculations constrained with measured data. The calculations were made with accounting for radical production from $\mathrm{HONO}, \mathrm{HCHO}$ and $\mathrm{O}_{3}$ photolysis and radical loss in reactions with $\mathrm{NO}$ and $\mathrm{NO}_{2}$ :

$\mathrm{L}_{\mathrm{R}}=k_{\mathrm{OH}+\mathrm{NO}}[\mathrm{OH}][\mathrm{NO}]+k_{\mathrm{OH}+\mathrm{NO}_{2}}[\mathrm{OH}]\left[\mathrm{NO}_{2}\right]$

$$
\begin{aligned}
\mathrm{P}_{\mathrm{R} 1}= & J(\mathrm{HONO})[\mathrm{HONO}] \\
& +2 J\left(\mathrm{O}^{1} \mathrm{D}\right)\left[\mathrm{O}_{3}\right] \Phi_{\mathrm{OH}_{1}}+2 J\left(\mathrm{HCHO}_{\mathrm{rad}}\right)[\mathrm{HCHO}]
\end{aligned}
$$

$P_{R}$ and $L_{R}$ represent, respectively, the production and loss rates (in molecule $\mathrm{cm}^{-3} \mathrm{~s}^{-1}$ ). The terms $k_{\mathrm{OH}+\mathrm{NO}}$ and $k_{\mathrm{OH}+\mathrm{NO}_{2}}$ represent the rate constants of the reactions between $\mathrm{OH}$ and $\mathrm{NO}$ and between $\mathrm{OH}$ and $\mathrm{NO}_{2}$, respectively, and are temperature and pressure dependent (Atkinson et al., 2004). $\Phi_{\mathrm{OH}_{1}}$ represents the fraction of $\mathrm{O}^{1} \mathrm{D}$ formed by ozone photolysis which will react with $\mathrm{H}_{2} \mathrm{O}$ to form $\mathrm{OH}$. This rate is calculated using known rate constants for $\mathrm{O}^{1} \mathrm{D}$ quenching reactions with $\mathrm{N}_{2}$ and $\mathrm{O}_{2}$ and known rate constants for reaction between $\mathrm{O}^{1} \mathrm{D}$ and water (Dunlea and Ravishankara, $2004 \mathrm{a}, \mathrm{b})$. Since the $J\left(\mathrm{HCHO}_{\mathrm{rad}}\right)$ was not measured, it has been estimated from the measured $J\left(\mathrm{NO}_{2}\right)$ and $J\left(\mathrm{O}^{1} \mathrm{D}\right)$ data using the parameterization by Holland et al. (2003). In addition to these photolysis processes, a large source of $\mathrm{OH}$ in urban area can come from non-photolytic processes such as ozonolysis of alkenes (Kanaya et al., 2007) resulting in a radical production rate given by:

$\mathrm{P}_{\mathrm{R} 2}=\mathrm{P}_{\mathrm{R} 1}+\sum k_{\mathrm{O}_{3}+\text { alkene }}[$ alkene $]\left[\mathrm{O}_{3}\right] \Phi_{\mathrm{OH}_{2}}$

$\Phi_{\mathrm{OH}_{2}}$ represents in this equation the radical (that is, $\mathrm{OH}$, $\mathrm{HO}_{2}, \mathrm{RO}, \mathrm{RO}_{2}, \mathrm{RCO}_{3}$ ) yields from the respective reactions between ozone and alkenes and $k_{\mathrm{O}_{3}}+$ alkene the rate constant of the reaction between $\mathrm{O}_{3}$ and an alkene (Calvert et al., 2000).

The Photo Stationary State assumes that the radical production rate is balanced by the radical loss rate $\left(\mathrm{P}_{\mathrm{R}}=\mathrm{L}_{\mathrm{R}}\right)$. Thus, the Photo Stationary State concentrations of $\mathrm{OH}$ derived from this equilibrium, considering the $\mathrm{P}_{\mathrm{R} 1}$ or $\mathrm{P}_{\mathrm{R} 2}$ production, are given by:

$[\mathrm{OH}]_{\mathrm{PSS} 1}=P_{\mathrm{R} 1} /\left(k_{\mathrm{OH}+\mathrm{NO}}[\mathrm{NO}]+k_{\mathrm{OH}+\mathrm{NO}_{2}}\left[\mathrm{NO}_{2}\right]\right)$ 
Table 1. Measurements and techniques during the MEGAPOLI summer campaign.

\begin{tabular}{|c|c|c|c|}
\hline Species & $\begin{array}{l}\text { Time resolution } \\
(\mathrm{min}) / 2 \sigma \text { uncertainties } \\
(\%) / \text { Detection limit }\end{array}$ & Instrumentation & Institution \\
\hline $\mathrm{OH}$ & $5 / 35 / 3.10^{5} \mathrm{~cm}^{-3}$ & CIMS SAMU & LATMOS \\
\hline ROx & $5 / 45 / 10^{6} \mathrm{~cm}^{-3}$ & CIMS SAMU & LATMOS \\
\hline NO & $1 / 5 / 0.5 \mathrm{ppb}$ & $\begin{array}{l}\text { Ozone } \\
\text { chemiluminescence }\end{array}$ & LISA \\
\hline $\mathrm{NO}_{2}$ & $1 / 5 / 0.5 \mathrm{ppb}$ & $\begin{array}{l}\text { Luminol } \\
\text { chemiluminescence }\end{array}$ & LISA \\
\hline $\mathrm{O}_{3}$ & $1 / 5 / 1 \mathrm{ppb}$ & UV absorption & LISA \\
\hline $\mathrm{CO}$ & $15 / 10 / 1 \mathrm{ppb}$ & GC-RGD & LSCE \\
\hline PAN & $15 / 10 / 10 \mathrm{ppt}$ & GC-ECD & LISA \\
\hline HONO & $10 / 12 / 5-10 \mathrm{ppt}$ & $\begin{array}{l}\text { Wet chemical } \\
\text { derivatization } \\
\text { (SA/NED)/HPLC detection } \\
\text { (NITROMAC) }\end{array}$ & LISA \\
\hline HCHO, other oxygenated compounds & $180 / 25 / 10 \mathrm{ppt}$ & DNPH cartridges & EMD, LISA \\
\hline VOC's $\left(\mathrm{C}_{3}-\mathrm{C}_{9}\right)$ & $30 / 15 / 50-100 \mathrm{ppt}$ & GC-FID & LISA \\
\hline VOC's $\left(\mathrm{C}_{7}-\mathrm{C}_{16}\right)$ & $180 / 25 / 10 \mathrm{ppt}$ & cartridges & EMD, LISA \\
\hline Aerosol Surface Area & $1 / \mathrm{nc} / \mathrm{nc}$ & Aerosol Particle Sizer & PSI \\
\hline $\begin{array}{l}\text { Photolysis frequencies } \quad(J(\mathrm{NO} 2), \quad J(\mathrm{O} 1 \mathrm{D}), \\
J(\mathrm{HONO}))\end{array}$ & $\begin{array}{l}1-10 / 20-25 / 10^{-7} \\
5.10^{-5} \mathrm{~s}^{-1}\end{array}$ & $\begin{array}{l}\text { Filterradiometres, } \\
\text { spectroradiometre (LI-1800) }\end{array}$ & LISA \\
\hline $\begin{array}{l}\text { RH, Temperature, Pressure, wind speed, wind } \\
\text { direction }\end{array}$ & $1 / \mathrm{nc} / \mathrm{nc}$ & $\begin{array}{l}\text { Wind sensor and multiplate } \\
\text { radiation shield (Young) }\end{array}$ & LISA \\
\hline Boundary Layer Height & $60 / \mathrm{nc} / \mathrm{nc}$ & Lidar & LMD \\
\hline
\end{tabular}

$$
[\mathrm{OH}]_{\mathrm{PSS} 2}=P_{\mathrm{R} 2} /\left(k_{\mathrm{OH}+\mathrm{NO}}[\mathrm{NO}]+k_{\mathrm{OH}+\mathrm{NO}_{2}}\left[\mathrm{NO}_{2}\right]\right)
$$

These calculations were performed only for the days of the campaign when all parameters involved in the calculations were available. Despite this restriction, seven days of calculations could be made and compared to observations. The concentrations of alkenes of anthropogenic origin were under the detection limit of the GC-FID instrument, which is about $100 \mathrm{ppt}$, during the whole study period, except for methylpropene. The concentrations of 10 linear or branched alkenes (from propene to heptene) have been set to $100 \mathrm{ppt}$ in the $\mathrm{OH} \mathrm{PSS} S_{2}$ calculation in order to have a high limit estimation of the impact of alkenes on $\mathrm{OH}$ quasi-stationary levels. In addition to ozonolysis of these 10 alkenes, the ozonolysis of isoprene, $\alpha$-pinene, $\beta$-pinene and limonene, all measured during MEGAPOLI, have been added to the $\mathrm{OH}$ source equation $(\mathrm{OH})_{\mathrm{PSS} 2}$.

\subsection{Box modelling with the Master Chemical Mechanism (MCM)}

A comprehensive analysis of the radical chemistry during the MEGAPOLI summer campaign requires the use of a model where all the $\mathrm{OH}, \mathrm{HO}_{2}$ and $\mathrm{RO}_{2}$ radical sources and sinks are taken into account. Radical concentrations and budgets were thus simulated with a box model constrained with all measured data using a detailed chemical scheme to represent organic chemistry. The MCM mechanism v3.1 (http: //mcm.leeds.ac.uk/MCM) (Jenkin et al., 1997, 2007; Saunders et al., 2003; Bloss et al., 2005) was implemented in a zero dimensional photochemical box model. This mechanism was updated for the inorganic chemistry with kinetic data from SAPRC 07 (http://www.engr.ucr.edu/ carter/ SAPRC/) (Carter, 2010). The MCM subset used in our model includes the oxidation of all measured organic species, containing around 5000 species and 14000 reactions. Time integration was solved in the model using the two-step solver (Verwer et al., 1994, 1996). 
Table 2. List of the 32 VOCs measured during MEGAPOLI summer campaign and constrained in the MCM model.

\begin{tabular}{|c|c|c|c|c|c|}
\hline \multicolumn{2}{|c|}{ Compound Name } & \multirow{2}{*}{$\begin{array}{r}\text { Time Resolution } \\
(\min )\end{array}$} & \multicolumn{3}{|c|}{ Mixing Ratio (ppb) } \\
\hline MCM & Name & & Max & Averaged & Median \\
\hline MEPROPENE & Isobutene & 30 & 2.5 & 0.52 & 0.32 \\
\hline IC4H10 & Isobutane & 30 & 0.78 & 0.25 & 0.2 \\
\hline NC4H10 & Butane & 30 & 2.2 & 0.32 & 0.24 \\
\hline C5H8 & Isoprene & 30 & 2.7 & 0.34 & 0.25 \\
\hline IC5H12 & Isopentane & 30 & 2 & 0.28 & 0.17 \\
\hline NC5H12 & Pentane & 30 & 0.9 & 0.17 & 0.12 \\
\hline TOLUENE & Toluene & 180 & 0.84 & 0.16 & 0.13 \\
\hline NC6H14 & Hexane & 30 & 0.27 & 0.1 & 0.09 \\
\hline EBENZ & Ethylbenzene & 180 & 0.12 & 0.03 & 0.02 \\
\hline MXYL & M-Xylene & 180 & 0.15 & 0.03 & 0.02 \\
\hline OXYL & O-Xylene & 180 & 0.13 & 0.03 & 0.03 \\
\hline PXYL & P-Xylene & 180 & 0.15 & 0.03 & 0.02 \\
\hline NC9H20 & Nonane & 180 & 0.07 & 0.01 & 0.01 \\
\hline APINENE & $\alpha$-Pinene & 180 & 0.23 & 0.04 & 0.03 \\
\hline BPINENE & $\beta$-Pinene & 180 & 0.03 & 0.01 & 0.01 \\
\hline $\mathrm{NC} 10 \mathrm{H} 22$ & Decane & 180 & 0.11 & 0.02 & 0.02 \\
\hline $\mathrm{NC} 11 \mathrm{H} 24$ & Undecane & 180 & 0.07 & 0.02 & 0.01 \\
\hline $\mathrm{NC} 12 \mathrm{H} 26$ & Dodecane & 180 & 0.12 & 0.02 & 0.01 \\
\hline $\mathrm{CH} 3 \mathrm{CHO}$ & Acetaldéhyde & 180 & 3.2 & 0.56 & 0.48 \\
\hline GLYOX & Glyoxal & 180 & 0.41 & 0.03 & 0.02 \\
\hline ACR & Acrolein & 180 & 0.09 & 0.01 & 0.01 \\
\hline $\mathrm{C} 2 \mathrm{H} 5 \mathrm{CHO}$ & Propanal & 180 & 0.42 & 0.05 & 0.04 \\
\hline $\mathrm{CH} 3 \mathrm{COCH} 3$ & Acetone & 180 & 6 & 1.2 & 1.1 \\
\hline MGLYOX & MethylGlyoxal & 180 & 0.4 & 0.05 & 0.04 \\
\hline MACR & Methacrolein & 180 & 0.41 & 0.05 & 0.03 \\
\hline MVK & Butenone & 180 & 1.6 & 0.3 & 0.25 \\
\hline $\mathrm{C} 3 \mathrm{H} 7 \mathrm{CHO}$ & Butanal & 180 & 0.05 & 0.01 & 0.01 \\
\hline MEK & Butanone & 180 & 8.6 & 1.7 & 1.5 \\
\hline C3ME3CHO & 3-Methylbutanal & 180 & 0.15 & 0.02 & 0.01 \\
\hline C4H9CHO & Pentanal & 180 & 0.08 & 0.01 & 0.01 \\
\hline C5H11CHO & Hexanal & 180 & 0.57 & 0.04 & 0.02 \\
\hline BENZAL & Benzaldéhyde & 180 & 0.31 & 0.02 & 0.02 \\
\hline
\end{tabular}

The model was constrained with 10 min values of the following measured environmental parameters: relative humidity (RH), temperature, pressure, boundary layer height, $J\left(\mathrm{O}^{1} \mathrm{D}\right), J\left(\mathrm{NO}_{2}\right)$ and $J(\mathrm{HONO})$. The non measured photolysis frequencies were calculated as a function of the solar zenith angle using the TUV radiation model and corrected with $J\left(\mathrm{O}^{1} \mathrm{D}\right)$ or $J\left(\mathrm{NO}_{2}\right)$ measurements. The calculated photolysis frequencies were multiplied by the ratio between measured and TUV calculated $J\left(\mathrm{O}^{1} \mathrm{D}\right)$ for species photolyzed at wavelengths smaller than $330 \mathrm{~nm}$ and by the ratio between measured and TUV calculated $J\left(\mathrm{NO}_{2}\right)$ for species photolyzed at wavelengths longer than $330 \mathrm{~nm}$.

The model was also constrained for stable species with 10 min measurements of $\mathrm{NO}, \mathrm{NO}_{2}, \mathrm{O}_{3}, \mathrm{CO}, \mathrm{CH}_{4}, \mathrm{CO}_{2}$, HCHO, HONO, PAN, and 32 VOCs (listed in Table 2). In order to create this $10 \mathrm{~min}$ database, the species concentrations were averaged or linearly interpolated depending on their time resolution (see Table 1). No measurement of ben- zene and propane were available during the campaign. For the modelling calculations the concentrations of benzene and propane were estimated using their quadratic relationship with, respectively, toluene and butane. These relationships obtained during a previous preparation campaign conducted in June-July 2008 at the SIRTA provide a good correlation with $R^{2}$ of 0.71 and 0.83 for benzene/toluene and propane/butane, respectively. In order to test the influence of these two species on radical chemistry and an eventual error caused by the estimation of their concentrations, sensitivity tests were conducted by varying their concentrations by a factor of 10 covering the full range of atmospheric concentrations of these species in a semi-urban environment. The multiplication of benzene concentration by 10 or 0.1 led to minor differences in radical concentrations simulated by the model: respectively $0.05 \%$ and $0.01 \%$ for $\mathrm{OH}, 0.60 \%$ and $0.06 \%$ for $\mathrm{HO}_{2}$ and $1.50 \%$ and $0.10 \%$ for $\mathrm{RO}_{2}$. Similar minor differences were observed for propane, since multiplying 
its concentration by 10 or 0.1 led, respectively, to modifications of $0.20 \%$ and $0.02 \%$ for $\mathrm{OH}, 0.60 \%$ and $0.06 \%$ for $\mathrm{HO}_{2}$ and $0.20 \%$ and $0.02 \%$ for $\mathrm{RO}_{2}$.

While most of the primary VOCs were measured, only some secondary VOCs were detected (HCHO, other aldehydes, some ketones...). These unmeasured secondary species could likely have an important influence on the $\mathrm{RO}_{\mathrm{x}}$ formation, propagation and termination rates (Emmerson et al., 2005b; Volkamer et al., 2010; Kato et al., 2011; Liu et al., 2012). The concentrations of unmeasured secondary organic species were estimated following three distinct methods described below.

Method 1: formation of secondary species from the oxidation of the measured compounds up to a daily stationary state. Each day (from midnight to midnight) was simulated several times, constraining each time the model with the same measured data, until daily stationary concentrations were reached for the unmeasured secondary species. This daily steady state for unmeasured compounds was reached after 5 days. Each day of the campaign was considered independently and the unmeasured species concentrations were set to zero at the beginning of the next day to simulate. Such an approach has been used several times for similar studies (Carslaw et al., 2001; Emmerson et al., 2007; Kanaya et al., 2007; Elshorbany et al., 2009; Bloss et al., 2010). This version of the model is referenced as the 5-day spin up model hereafter and will be used as the reference model.

Method 2: accumulation of secondary species formed from the oxidation of measured compounds during a few hours at each data point. We have considered an accumulation time of 1 or $2 \mathrm{~h}$. The unmeasured concentrations of secondary species were simulated for each $10 \mathrm{~min}$ data point for a prescribed time period (i.e. 1 or $2 \mathrm{~h}$ ) with the constrained measured parameters held constant. As each 10 min dataset was considered independently, the concentrations of unmeasured species are then set to zero for the next time step of the simulation. These two model versions are referenced hereafter as the cumul $1 \mathrm{~h}$ model and the cumul $2 \mathrm{~h}$ model, respectively. The correlations between the radical concentrations determined with these two cumulative approaches and with the 5-day spin up model are presented in Fig. 1 (panel a to f). Compared to the reference model, the simulated $\mathrm{OH}$ concentrations are increased by $2.7 \%$ for the cumul $1 \mathrm{~h}$ model while no modification are found for the cumul2h model; simulated $\mathrm{HO}_{2}$ and $\mathrm{RO}_{2}$ concentrations are reduced by $19 \%$ and $30 \%$ for the cumul $1 \mathrm{~h}$ model respectively and by $16 \%$ and $23 \%$ for the cumul2h model respectively. These results can be explained by the lower concentrations obtained for the unconstrained secondary VOCs with the $1 \mathrm{~h}$ and $2 \mathrm{~h}$ accumulation model versions.

Method 3: dilution of secondary species formed from the oxidation of measured compounds. The model was run over the full campaign, constrained with the 10 min measured data, with a dilution loss corresponding to a residence time of 1 or $2 \mathrm{~h}$ for unmeasured secondary species. A 2-day spin up period was run at the beginning of the simulation to allow unconstrained VOCs to reach a stationary state. These versions of the model are called hereafter $1 \mathrm{~h}$ dilution model and $2 \mathrm{~h}$ dilution model. The correlations between the radical concentrations obtained by these two approaches and the radical concentrations obtained with the reference model are shown in Fig. 1 (panel g to 1). No significant differences are found between the radical concentrations estimated by the reference model and the ones estimated by the $2 \mathrm{~h}$ dilution model $\left(0.4,0.9,2.7 \%\right.$ for $\mathrm{OH}, \mathrm{HO}_{2}$ and $\mathrm{RO}_{2}$ respectively). Higher differences are found for the $1 \mathrm{~h}$ dilution model. Indeed, modelled $\mathrm{OH}$ concentrations are increased by $7.1 \%$ and modelled $\mathrm{HO}_{2}$ and $\mathrm{RO}_{2}$ concentrations are reduced by 31 and $39 \%$ respectively. These differences result from the lower concentrations simulated with the $1 \mathrm{~h}$ dilution model for the non measured VOC.

None of these approaches is fully satisfactory to estimate the unmeasured VOCs concentrations (see Supplement S2). However, the various versions of the model are expected to encompass the concentration of non measured secondary VOC and therefore their influence on radical budget. Thus, two contrasted versions, the reference and the $1 \mathrm{~h}$ dilution, will be used for the comparison between measurement and model results.

Finally, dry deposition rates were assigned to stable species in the model and applied over the boundary layer for which the height was constrained in the model using in situ observations made at the measurement site (Haeffelin et al., 2011). The deposition velocities were taken from Derwent (1996) for $\mathrm{NO}_{2}\left(0.15 \mathrm{~cm} \mathrm{~s}^{-1}\right), \mathrm{HNO}_{3}\left(2 \mathrm{~cm} \mathrm{~s}^{-1}\right)$, $\mathrm{O}_{3}\left(0.5 \mathrm{~cm} \mathrm{~s}^{-1}\right), \mathrm{SO}_{2}\left(0.5 \mathrm{~cm} \mathrm{~s}^{-1}\right)$, PAN $\left(0.2 \mathrm{~cm} \mathrm{~s}^{-1}\right.$, assumed the same for all PANs species) and from Brasseur et al. (1998) for $\mathrm{HCHO}\left(0.33 \mathrm{~cm} \mathrm{~s}^{-1}\right.$, assumed the same for all aldehydes), $\mathrm{H}_{2} \mathrm{O}_{2}\left(1.1 \mathrm{~cm} \mathrm{~s}^{-1}\right)$, methyl- and ethyl- nitrate $\left(1.1 \mathrm{~cm} \mathrm{~s}^{-1}\right.$, assumed the same for all organic nitrates), and $\mathrm{CH}_{3} \mathrm{OOH}\left(0.55 \mathrm{~cm} \mathrm{~s}^{-1}\right.$ and assumed the same for all organic peroxides). For the multifunctional species, the highest deposition velocity by function was adopted. This means that if a species own several functions, the deposition velocity applied to this species is the one of the functions which has the highest deposition velocity. For the remaining MCM species, the dry deposition velocities have been set to a default value of $0.5 \mathrm{~cm} \mathrm{~s}^{-1}$. A test was performed to evaluate the sensitivity to this default deposition velocity and simulations were conducted using values in the $0-2 \mathrm{~cm} \mathrm{~s}^{-1}$ range. The results show a low impact on the simulated radical concentrations. These results are reported in Table 3.

\section{Results and discussion}

\subsection{Overview of measurement results}

The measured concentration of inorganic species $\left(\mathrm{NO}_{\mathrm{x}}, \mathrm{O}_{3}\right.$ and $\mathrm{HONO})$ and radical species $\left(\mathrm{OH}\right.$ and $\left(\mathrm{HO}_{2}+\mathrm{RO}_{2}\right)$ ) 

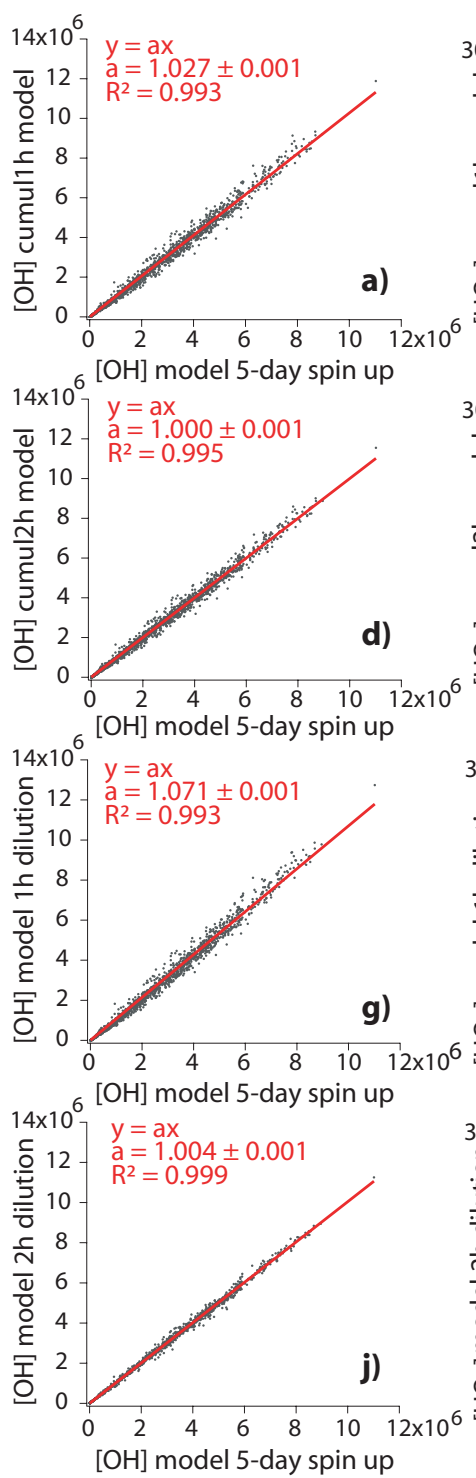

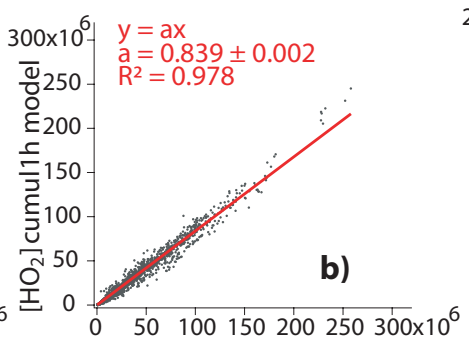

$\left[\mathrm{HO}_{2}\right]$ model 5-day spin up

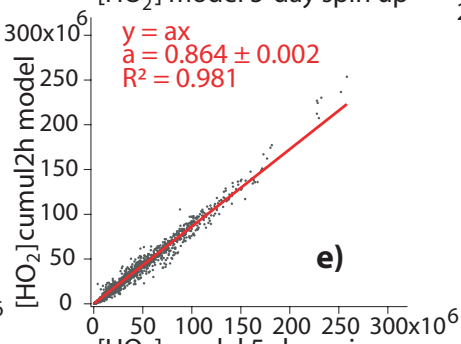

$\left[\mathrm{HO}_{2}\right]$ model 5-day spin up

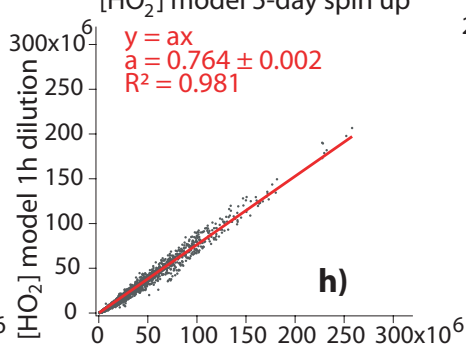

$\left[\mathrm{HO}_{2}\right]$ model 5-day spin up

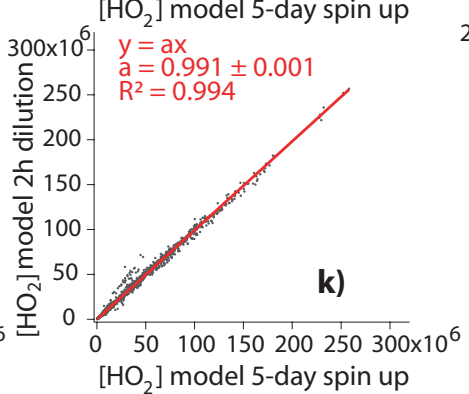

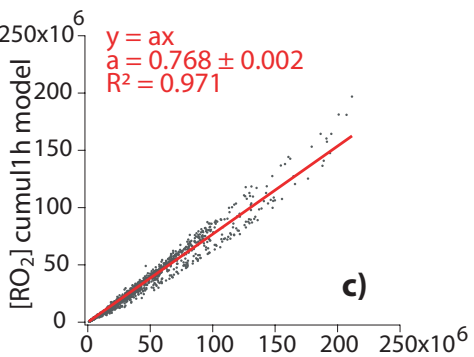
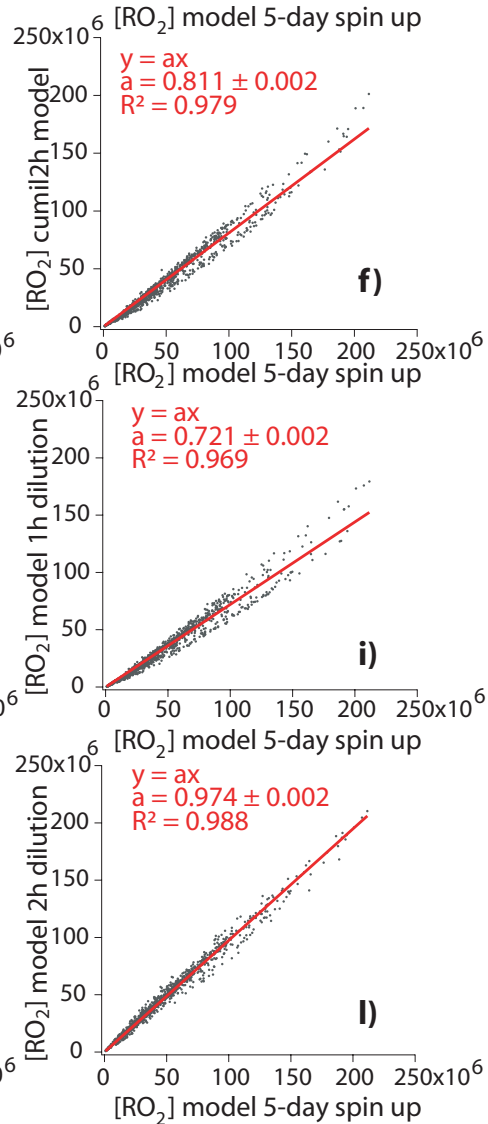

Fig. 1. Correlation between radical concentrations simulated by the three modelling procedures presented in Sect. 3.2. The panels (a) to (c) represent the correlations of radical concentrations $\left(\mathrm{OH}, \mathrm{HO}_{2}\right.$ and $\left.\mathrm{RO}_{2}\right)$ simulated by the cumul1h model and by the 5 days spin up model. The panels (d) to (f)) represent the correlations of radical concentrations simulated by the cumul2h model and by the 5 days spin up model. The panels (g) to (i) represent the correlations of radical concentrations simulated by the $1 \mathrm{~h}$ dilution model and by the 5 days spin up model. Finally, the panels (j) to (l) represent the correlations of radical concentrations simulated by the $2 \mathrm{~h}$ dilution model and the 5 days spin up model.

between the 9-26 July 2009 are shown in Fig. 2 together with the $J\left(\mathrm{O}^{1} \mathrm{D}\right)$ and wind direction. The mean diurnal profiles averaged every $10 \mathrm{~min}$ over the campaign period are shown in Fig. 3. During the campaign, cloudy weather conditions were prevailing with temperatures ranging between $283 \mathrm{~K}$ during the night and $305 \mathrm{~K}$ for the rare sunny days. The wind came mainly from westerly and south-westerly sectors bringing clean oceanic air masses. Some rare events with the wind coming from the east or south-east sectors resulted in more polluted air masses from more urbanised areas or, at least because of a longer residence time above continental land (Freutel et al., 2012) (e.g. on 21 July with concentrations of $\mathrm{NO}_{2}, \mathrm{O}_{3}$ and $\mathrm{OH}$ reaching on this day, $25 \mathrm{ppb}, 70 \mathrm{ppb}$ and $1.06 \times 10^{7}$ molecule $\mathrm{cm}^{-3}$ respectively).

During the whole studied period, $\mathrm{OH}$ concentrations exhibited a clear diurnal profile with daytime maxima of (3.510.1) $\times 10^{6}$ molecule $\mathrm{cm}^{-3}$ with mean maximum value of $4.2 \times 10^{6}$ molecule $\mathrm{cm}^{-3}$ at about 13:30 local time (LT). Diurnal variation of $J\left(\mathrm{O}^{1} \mathrm{D}\right)$ was similar to that of $\mathrm{OH}$ with an average daytime maximum around 14:00 LT of 

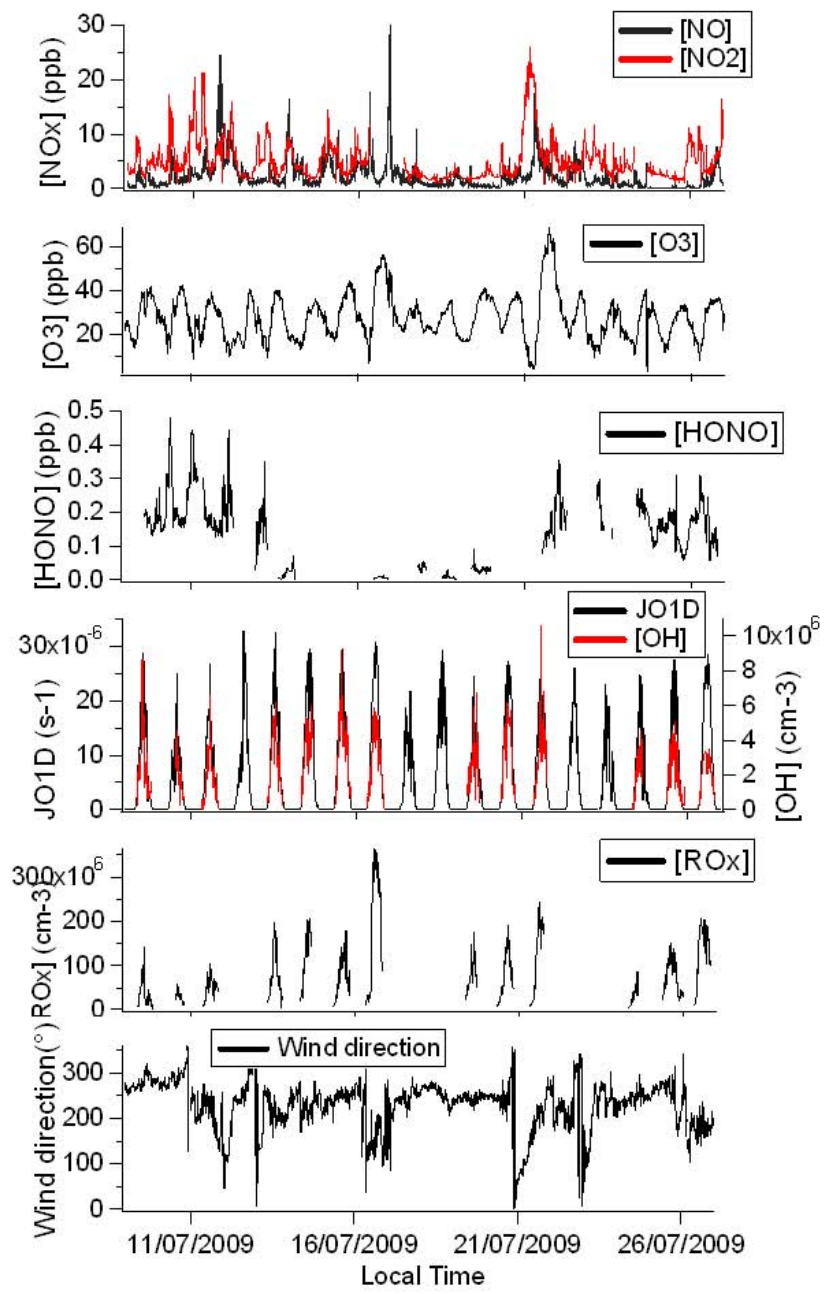

Fig. 2. 10 min data of $\mathrm{NO}_{\mathrm{x}}, \mathrm{O}_{3}, \mathrm{HONO}, J\left(\mathrm{O}^{1} \mathrm{D}\right), \mathrm{OH}, \mathrm{RO}_{\mathrm{x}}$ and wind direction during the MEGAPOLI summer field campaign in Palaiseau, 9-26 July 2009.

about $2.2 \times 10^{-5} \mathrm{~s}^{-1}$. The correlation between $\mathrm{OH}$ and $J\left(\mathrm{O}^{1} \mathrm{D}\right)$ is discussed in Supplement S3. The $\left(\mathrm{HO}_{2}+\mathrm{RO}_{2}\right)$ mean diurnal profile showed maximum value of about $1.4 \times 10^{8}$ molecule $\mathrm{cm}^{-3}$ around 14:00 LT.

$\mathrm{O}_{3}$ showed a typical diurnal variation with averaged daytime maxima values of $38 \mathrm{ppb}$ at about 17:00 LT. The mean daytime rush hour maxima for $\mathrm{NO}$ and $\mathrm{NO}_{2}$ at around 07:00 LT were $4 \mathrm{ppb}$ and $8 \mathrm{ppb}$, respectively. The HONO concentration levels were variable, up to $500 \mathrm{ppt}$, with the averaged daytime maximum of 210 ppt at around 09:00 LT. Furthermore, a detailed discussion of VOC results at SIRTA observatory can be found in Ait-Helal et al. (2012).

During MEGAPOLI summer campaign, the measurement site was thus characterised by intermediate $\mathrm{NO}_{\mathrm{x}}$ levels $(7 \mathrm{ppb}$ in average for $\mathrm{NO}_{\mathrm{x}}, 2.3 \mathrm{ppb}$ and $5.1 \mathrm{ppb}$ on average for $\mathrm{NO}$ and $\mathrm{NO}_{2}$, respectively) and quite low $\mathrm{O}_{3}$ levels (30 ppb in average). This is comparable with observations made in another suburban site in England, $40 \mathrm{~km}$ North-East of London
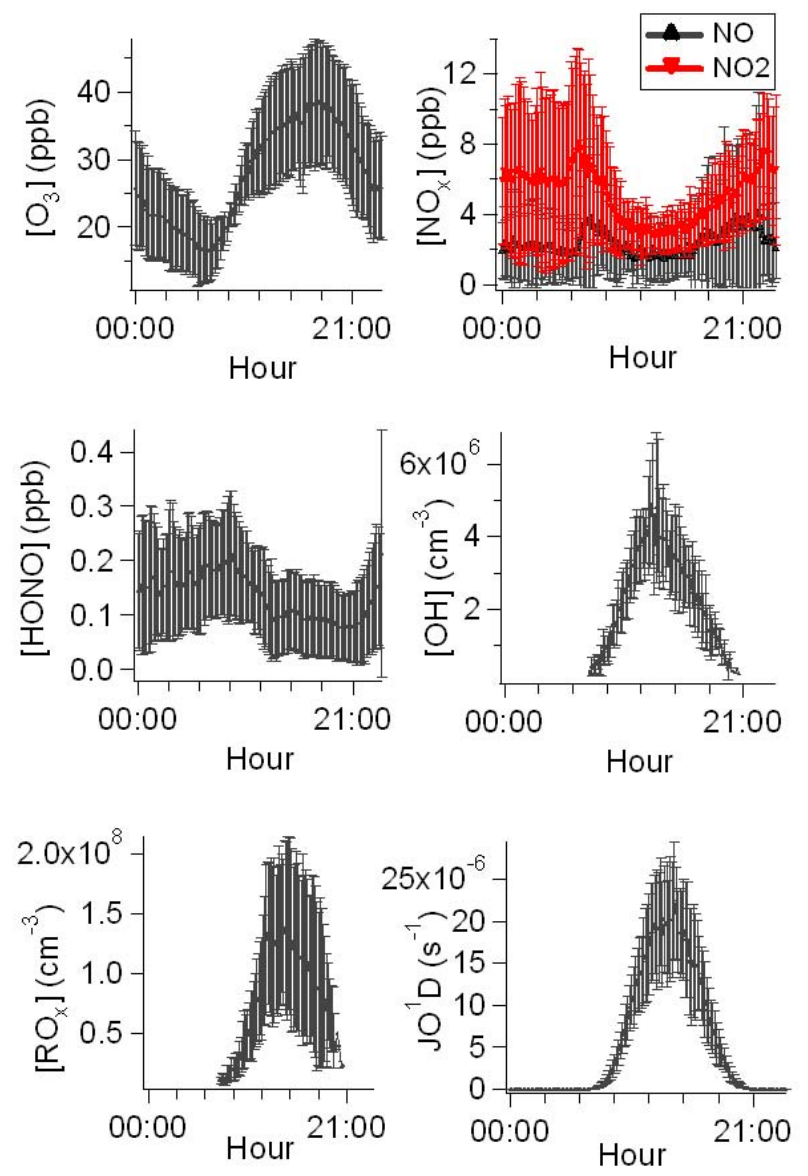

Fig. 3. Average diurnal $10 \mathrm{~min}$ profiles for $\mathrm{O}_{3}, \mathrm{NO}_{\mathrm{x}}, \mathrm{HONO}, \mathrm{OH}$, $\left(\mathrm{HO}_{2}+\mathrm{RO}_{2}\right)$ and $J\left(\mathrm{O}^{1} \mathrm{D}\right)$ during the MEGAPOLI summer campaign. Error bars correspond to standard deviation for the day to day variability.

in 2003 (Emmerson et al., 2007) with similar NO concentrations (2.9 ppb in average), but higher oxidant levels, i.e. $\mathrm{NO}_{2}$ and $\mathrm{O}_{3}\left(7.9 \mathrm{ppb}\right.$ and $46 \mathrm{ppb}$ on average for $\mathrm{NO}_{2}$ and $\mathrm{O}_{3}$, respectively). This can be explained by the presence of a heatwave period during the UK TORCH campaign while cloudy weather conditions were prevailing during the MEGAPOLI summer campaign. The $\mathrm{NO}_{\mathrm{x}}$ and $\mathrm{O}_{3}$ levels encountered during the MEGAPOLI summer campaign are also very close to the ones observed during the PUMA campaign (Emmerson et al., 2005a), taking place $4 \mathrm{~km}$ south west from Birmingham city centre, when Atlantic air masses from the westerly sector reached the PUMA campaign measurement site (2.7 ppb, 6.6 ppb and $29 \mathrm{ppb}$ on average for $\mathrm{NO}, \mathrm{NO}_{2}$ and $\mathrm{O}_{3}$, respectively). However, for air masses coming from the easterly sector and passing over Birmingham city centre before arriving at the measurement site, higher $\mathrm{NO}_{\mathrm{x}}$ and $\mathrm{O}_{3}$ levels were observed (4.2 ppb, 14.4 ppb and $41.2 \mathrm{ppb}$ in average for $\mathrm{NO}, \mathrm{NO}_{2}$ and $\mathrm{O}_{3}$, respectively). 

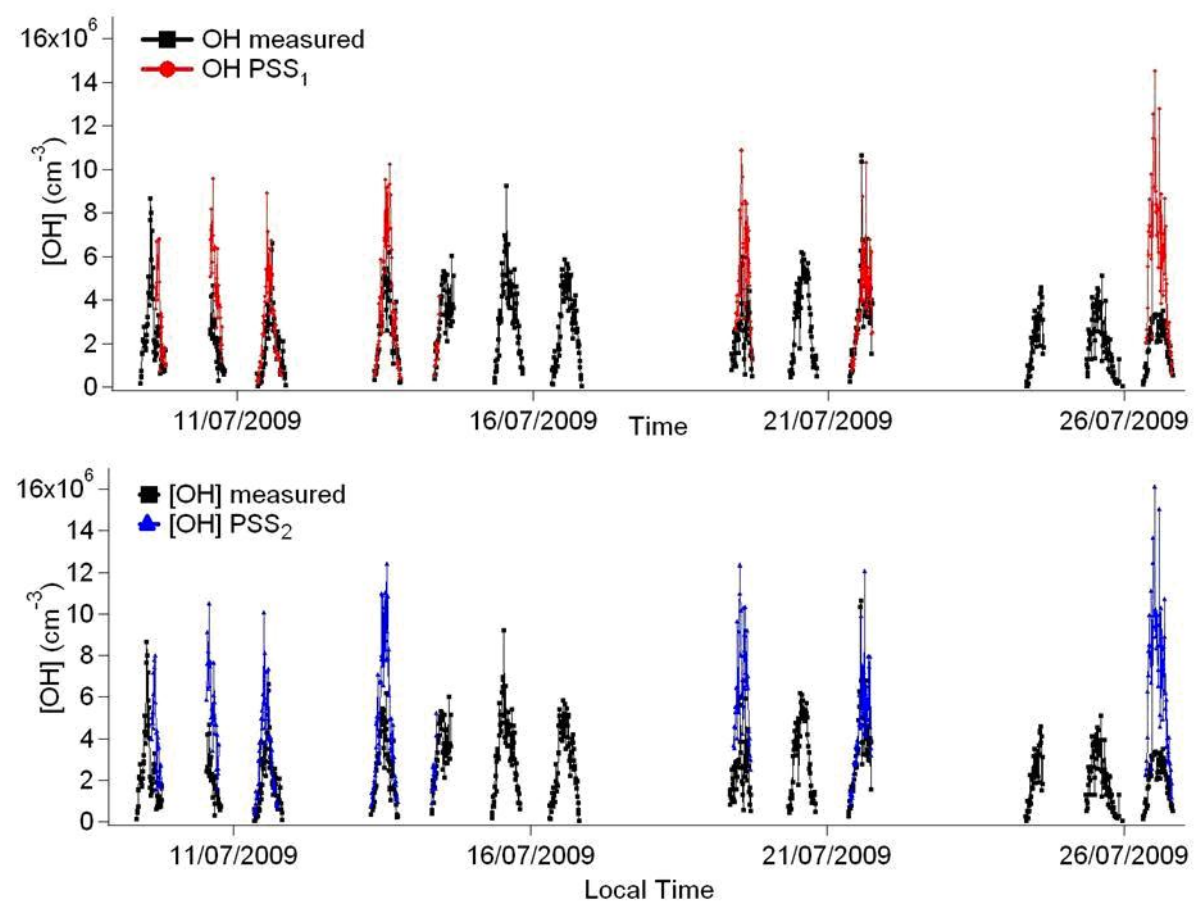

Fig. 4. Observed OH concentrations (black squares) compared with two PSS calculations including (PSS2) or not (PSS1) the ozonolysis of alkenes as $\mathrm{OH}$ source. The calculations of both PSS approaches are carried out only when all the parameters used in it are available.

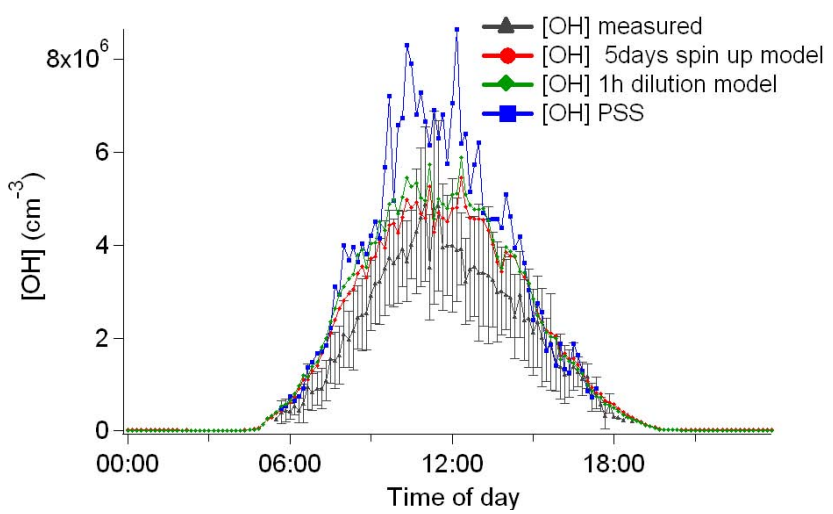

Fig. 5. Mean diurnal profiles of observed $[\mathrm{OH}]$ concentrations (black triangles), simulated $[\mathrm{OH}]$ concentrations with 5-day spin up approach (red circles) and with dilution of $1 \mathrm{~h}$ lifetime approach (green diamonds) and $[\mathrm{OH}]$ calculated concentrations by PSS. The PSS results shown here are from Eq. (R4) (OH PSS1). Error bars correspond to standard deviation for day to day variability.

\subsection{Comparison between PSS and measurement of $\mathrm{OH}$ concentrations}

To assess if the radical chemistry in the suburban environment of Palaiseau can be explained by a simple Photo Stationary State approach, a comparison between PSS calculations and $\mathrm{OH}$ measurements has been made as presented in Fig. 4 (panel $\mathrm{a}$ and $\mathrm{b}$ respectively for $(\mathrm{OH})_{\mathrm{PSS} 1}$ and
$[\mathrm{OH}]_{\mathrm{PSS} 2}$ ) for the whole study period and in Fig. 5 for the average diurnal profiles. Correlations between observed and calculated $\mathrm{OH}$ concentrations from both PSS Eqs. (R4-R5) are shown in Fig. 6.

These comparisons show a large overestimation of $\mathrm{OH}$ by both PSS calculations. Figure 6 shows an overestimation of measurements of a factor of 1.50 for OH $\mathrm{PSS}_{1}$ and 1.78 for $\mathrm{OH} \mathrm{PSS}_{2}$ on average. Including $\mathrm{OH}$ production via ozonolysis of alkenes leads to a rise of about $18 \%$ of the $\mathrm{OH}$ concentrations calculated via PSS. This increase is a higher limit of the influence of alkenes on $\mathrm{OH}$ concentrations as the concentration of undetected alkenes has been set to the detection limit concentration of the instrument. Considering only measured alkenes in $[\mathrm{OH}]_{\mathrm{PSS} 2}$ calculation, mainly methylpropene and isoprene, the increase of $\mathrm{OH}$ concentrations calculated via $\mathrm{PSS}_{2}$ is only about $3 \%$ compared with $[\mathrm{OH}]_{\mathrm{PSS} 1}$.

Dependence of the ratio between calculated (via $\mathrm{PSS}_{1}$ ) and observed $\mathrm{OH}$ concentrations is shown in Fig. 7 as a function of $\mathrm{NO}_{\mathrm{x}}$. The $\mathrm{OH}$ concentration tends to be in good agreement at high $\mathrm{NO}_{\mathrm{x}}$ levels, with the ratio between calculation and observation near unity when $\mathrm{NO}_{\mathrm{x}}$ is higher than $10 \mathrm{ppb}$. The PSS approach appears to be sufficient to explain $\mathrm{OH}$ concentrations in polluted environments, as it has been already shown in the highly polluted urban area of Santiago, Chile (Elshorbany et al., 2009), where similar $\mathrm{OH}$ concentrations are calculated (but not measured) by both the PSS approach and a box model containing the MCM and constrained with measurements. At lower $\mathrm{NO}_{\mathrm{x}}$, the $\mathrm{OH}$ 

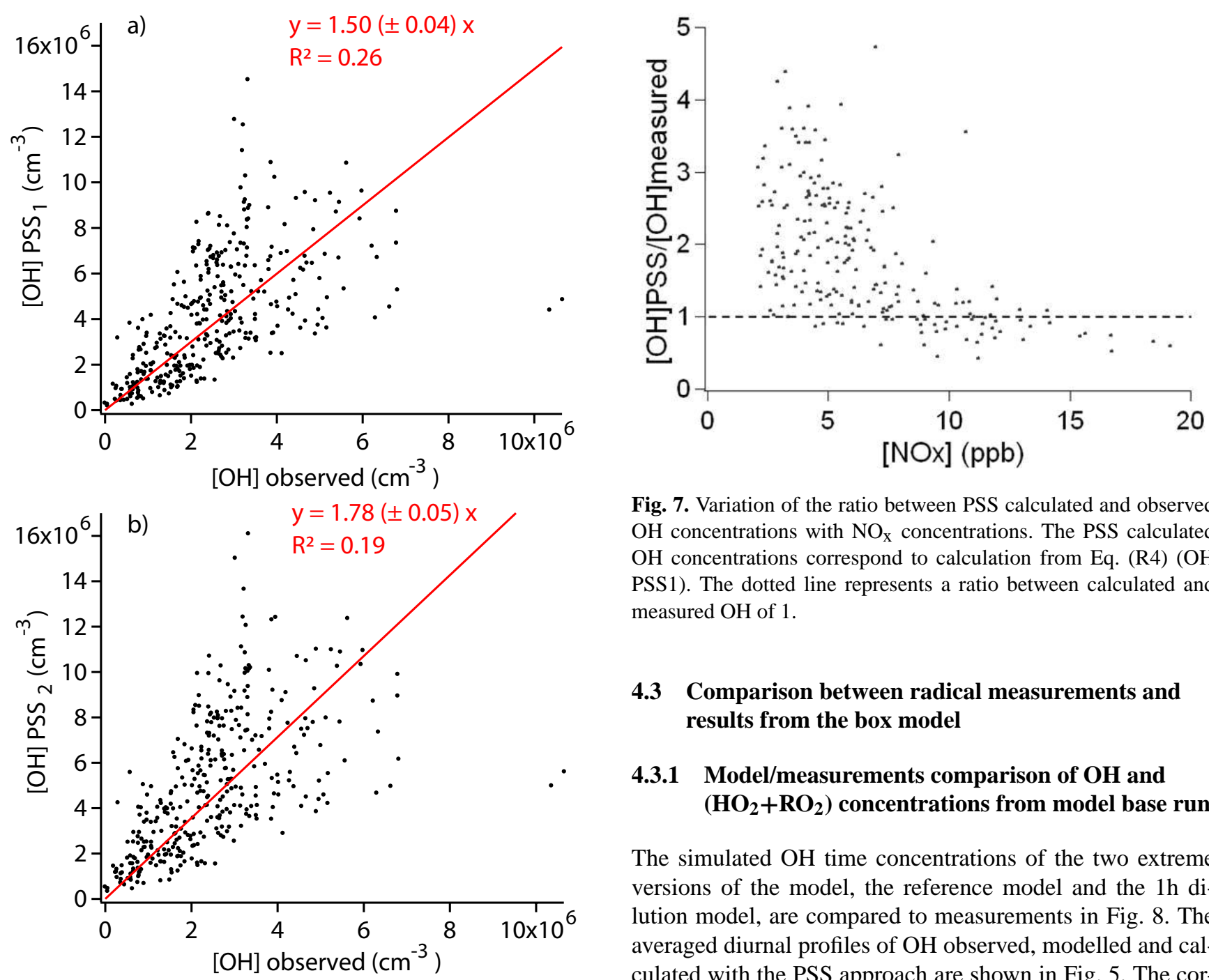

Fig. 7. Variation of the ratio between PSS calculated and observed $\mathrm{OH}$ concentrations with $\mathrm{NO}_{\mathrm{x}}$ concentrations. The PSS calculated $\mathrm{OH}$ concentrations correspond to calculation from Eq. (R4) $(\mathrm{OH}$ PSS1). The dotted line represents a ratio between calculated and measured $\mathrm{OH}$ of 1 .

\subsection{Comparison between radical measurements and results from the box model}

\subsubsection{Model/measurements comparison of $\mathrm{OH}$ and $\left(\mathrm{HO}_{2}+\mathrm{RO}_{2}\right)$ concentrations from model base run}

The simulated $\mathrm{OH}$ time concentrations of the two extreme versions of the model, the reference model and the $1 \mathrm{~h} \mathrm{di-}$ lution model, are compared to measurements in Fig. 8. The averaged diurnal profiles of $\mathrm{OH}$ observed, modelled and calculated with the PSS approach are shown in Fig. 5. The correlation between modelled and measured $\mathrm{OH}$ concentrations is presented in Fig. 9.

The model is in pretty good agreement with the observations for several days of the campaign $(07 / 09 ; 07 / 11 ; 07 / 13$; $07 / 15 ; 07 / 19 ; 07 / 20 ; 07 / 21)$, the difference being within the measurements uncertainties. Indeed, the differences between the simulated and measured $\mathrm{OH}$ concentrations on these days is lower than $15 \%$ in average using the reference model and lower than $25 \%$ in average using the $1 \mathrm{~h}$ dilution model. On some other days, the model largely overestimates $\mathrm{OH}$ measurements $(07 / 10 ; 07 / 14 ; 07 / 24 ; 07 / 25 ; 07 / 26)$. This overestimation is comprised, in average, between 38 and $67 \%$ for the reference model and between 50 and $78 \%$ for the $1 \mathrm{~h}$ dilution model on these days. This overestimation between simulated and measured $\mathrm{OH}$ concentrations even reaches almost a factor of 2 on the 24th. The averaged diurnal profiles presented in Fig. 5 show that the model leads to a serious improvement of the estimation of the $\mathrm{OH}$ concentrations compared to the PSS calculations. Correlations between observed and simulated $\mathrm{OH}$ concentrations have been performed only when the measurements of the following constrained species were all 


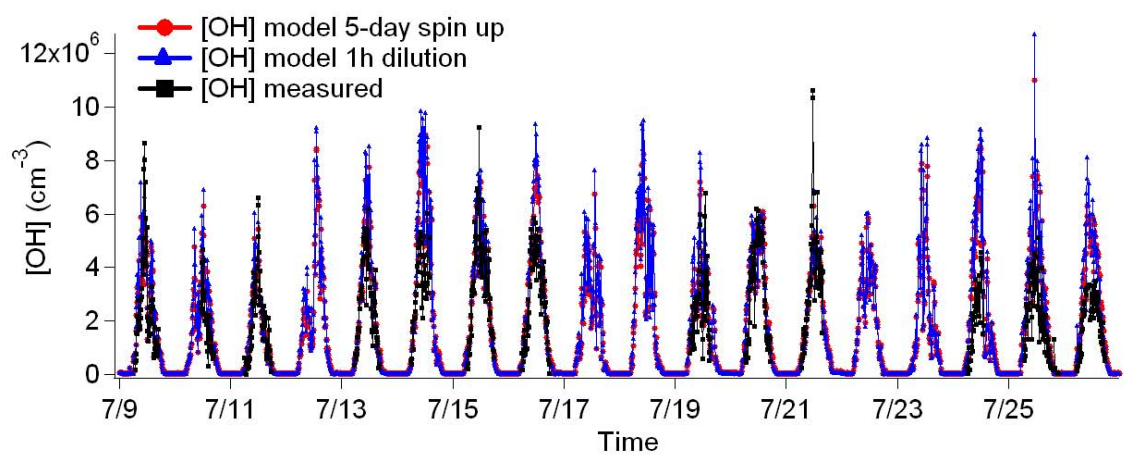

Fig. 8. Observed $[\mathrm{OH}]$ concentrations (black squares) compared with simulated $[\mathrm{OH}]$ concentrations by 5-day spin up scenario (red circles) and by 1 h-dilution scenario (blue triangles) by MCM v3.1 implemented in a OD boxmodel (see Sect. 3.2).
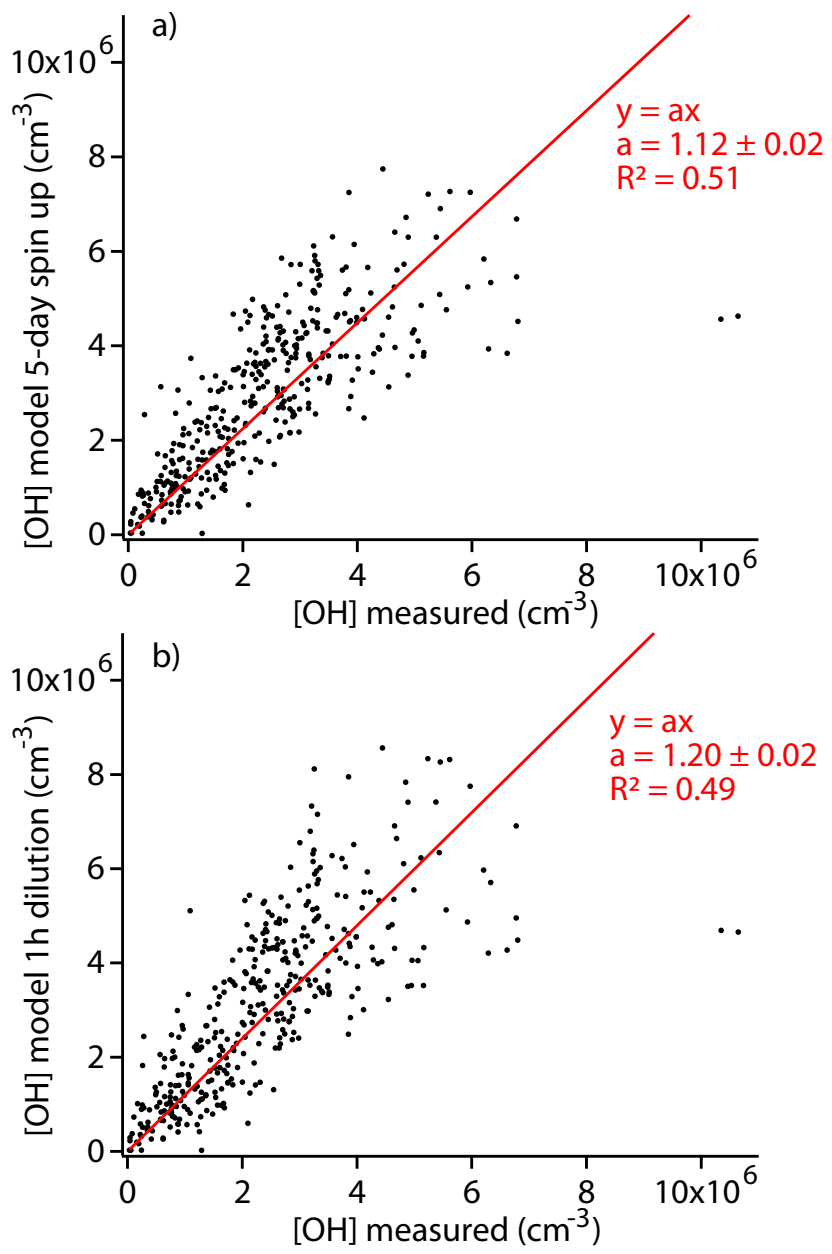

Fig. 9. Correlations between measured and modelled $[\mathrm{OH}]$ by two approaches for the whole study period. The red line represents linear regression forced by origin, with a slope of 1.12 and a correlation coefficient $R^{2}$ of 0.51 for the 5-day spin up model approach (a) and a slope of 1.20 and a correlation coefficient $R^{2}$ of 0.49 for the $1 \mathrm{~h}$ dilution model approach (b). available: $\mathrm{O}_{3}, \mathrm{CO}, \mathrm{NO}, \mathrm{NO}_{2}, \mathrm{HONO}$ and $\mathrm{HCHO}$. The linear regression slope between the modelled and observed $\mathrm{OH}$ concentrations are between 1.12 and 1.20 for various model versions whereas the one found for the correlation with $\mathrm{PSS}_{1}$ calculations (Fig. 6) was 1.50. However, some discrepancies still remain and have to be investigated. Figure S4 in Supplement shows the evolution of the ratio between modelled (with the reference scenario) and observed $\mathrm{OH}$ concentrations with $\mathrm{NO}_{\mathrm{x}}$ concentrations. No clear relationship can be found between $\mathrm{NO}_{\mathrm{x}}$ levels and overestimation from the model, as it has been shown for the PSS calculations (Fig. 7). Thus, the model including a detailed description of radical sources and sinks enables to represent the processes involved in $\mathrm{OH}$ budget under intermediate and low $\mathrm{NO}_{\mathrm{x}}$ levels better than the PSS calculations.

Simulated and measured peroxy radical $\left(\mathrm{HO}_{2}+\Sigma \mathrm{RO}_{2}\right)$ concentrations are compared in Fig. 10. Most of the time, the two extreme model versions allow to encompass the measured $\left(\mathrm{HO}_{2}+\mathrm{RO}_{2}\right)$ concentrations $(7 / 9 ; 7 / 10 ; 7 / 11 ; 7 / 13$; $7 / 14 ; 7 / 15 ; 7 / 19 ; 7 / 21 ; 7 / 25 ; 7 / 26)$. However, both versions of the model largely overestimate measured $\left(\mathrm{HO}_{2}+\mathrm{RO}_{2}\right)$ concentrations on $7 / 20$ (by $76 \%$ in average for the reference model and $33 \%$ in average for the $1 \mathrm{~h}$ dilution model) and $7 / 24$ (by $150 \%$ in average for the reference model and $96 \%$ in average for the $1 \mathrm{~h}$ dilution model) and underestimate the measurements on $7 / 16$ (by $30 \%$ in average for the reference model and $90 \%$ in average for the $1 \mathrm{~h}$ dilution model). The $\mathrm{NO}_{\mathrm{x}}$ levels were quite low on $7 / 20$ and $7 / 24\left(\mathrm{NO}_{\mathrm{x}}\right.$ concentrations being lower than $5 \mathrm{ppb}$ during these two days) and quite high on 7/16 (NO concentrations reaching $18 \mathrm{ppb}$ in the morning and $30 \mathrm{ppb}$ in the evening). However, such $\mathrm{NO}_{\mathrm{x}}$ levels were also encountered on some other days of the campaign without leading to similar trends in model discrepancies. Indeed, no clear relationship can be found between $\mathrm{NO}_{\mathrm{x}}$ levels and model discrepancies (not shown). An analysis of retroplume calculations, performed using the FLEXPART model (Stohl et al., 2005), on these days shows no evidence of clear differences in air mass origins compared with other days. Indeed, similar retroplume origin is found 


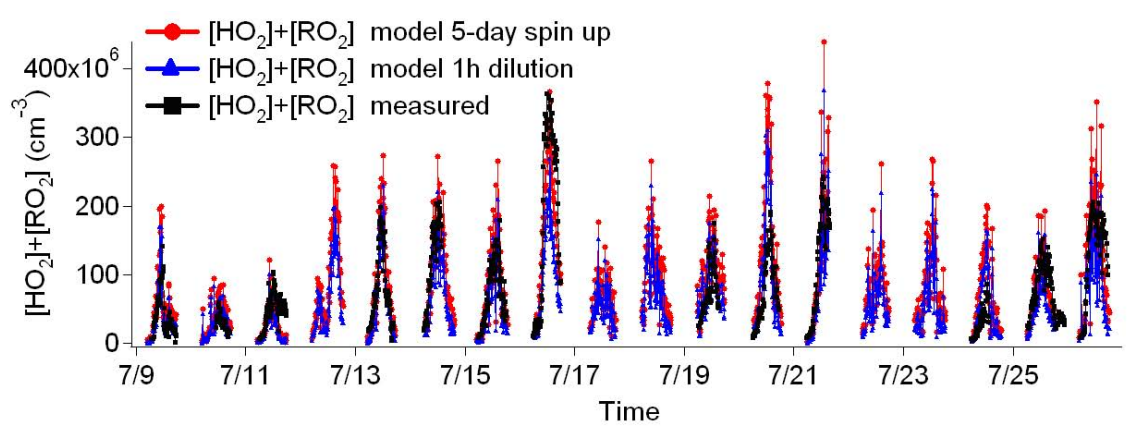

Fig. 10. Observed $\left(\mathrm{HO}_{2}+\mathrm{RO}_{2}\right)$ concentrations (black squares) compared to $\left(\mathrm{HO}_{2}+\mathrm{RO}_{2}\right)$ concentrations simulated by the 5-day spin up model approach (red circles) and by the $1 \mathrm{~h}$ dilution model approach (blue triangles) by MCM v3.1 implemented in a $0 \mathrm{D}$ boxmodel (see Sect. 3.2).

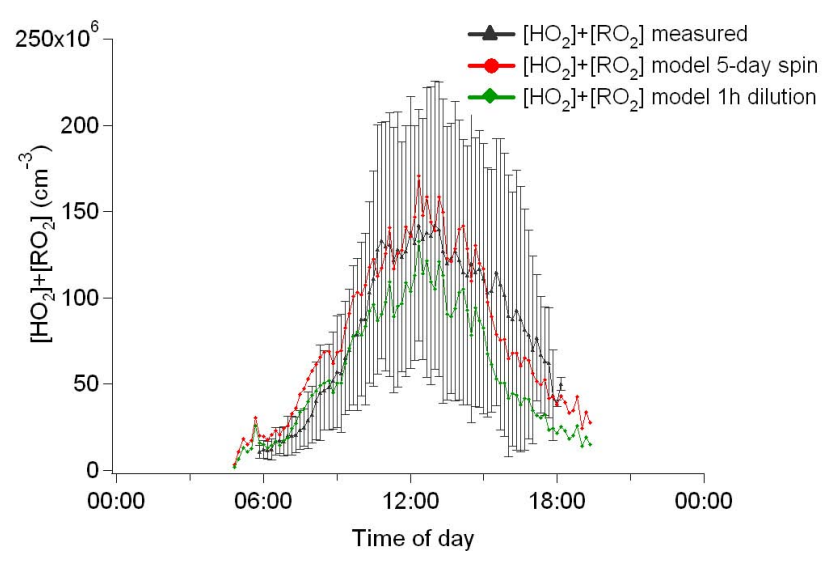

Fig. 11. Diurnal profiles of observed $\left(\mathrm{HO}_{2}+\mathrm{RO}_{2}\right)$ concentrations (black triangles) and simulated $\left(\mathrm{HO}_{2}+\mathrm{RO}_{2}\right)$ concentrations by the 5-day spin up model approach (red circles) and by the $1 \mathrm{~h}$ dilution model approach (green diamonds). Error bars correspond to standard deviation for day-to-day variability of measured $\left(\mathrm{HO}_{2}+\mathrm{RO}_{2}\right)$.

for $07 / 16$ and $07 / 21$ and for $07 / 20,07 / 24,07 / 14$ and 07/19, while no similar trends in model discrepancies are found for these days. The correlations between measured and simulated peroxy radical concentrations (see Fig.12) lead to good agreement on average with a slight overestimation of the reference model by a factor of 1.05 and an underestimation for the $1 \mathrm{~h}$ dilution model with a slope of 0.76 . As for $\mathrm{OH}$ correlation, these correlations apply only to the data where constraints for concentrations of $\mathrm{O}_{3}, \mathrm{CO}, \mathrm{NO}, \mathrm{NO}_{2}, \mathrm{HONO}$ and $\mathrm{HCHO}$ were not missing. The averaged diurnal profiles of measured and modelled $\left(\mathrm{HO}_{2}+\mathrm{RO}_{2}\right)$ concentrations are shown in Fig. 11. The model using both scenarios allows reproducing the diurnal profile of measured $\left(\mathrm{HO}_{2}+\mathrm{RO}_{2}\right)$ concentrations within the measurement uncertainties on average.

\subsection{2 $\mathrm{OH}, \mathrm{HO}_{2}$ and $\mathrm{RO}_{2}$ sensitivity to model constraints}

Sensitivity tests have been performed to identify the parameters, measured or missing, that could have the largest im- pact on simulated radical concentrations. The model used to perform sensitivity tests is the 5-day spin up version of the model (reference model version). The changes induced by the various perturbations on $\mathrm{OH}, \mathrm{HO}_{2}$ and sum of organic peroxy radicals $\mathrm{RO}_{2}$ concentrations are summarised in Table 3 and plotted in Fig. 13.

Most of the alkenes were present at a lower concentration than the detection limit of the instruments during the campaign. Even if present at low level, the impact of alkenes ozonolysis on radical formation can be important. Simulations have thus been conducted setting the concentrations of 12 branched or linear alkenes (from propene to hexene) to $100 \mathrm{ppt}$ and $50 \mathrm{ppt}$ respectively which corresponds to the upper estimation of the detection limit of the instrument and half of this detection limit. These simulations lead to a rise of radical concentrations in the model, with a larger impact of alkene ozonolysis on radical concentrations $\left(\mathrm{OH}, \mathrm{HO}_{2}\right.$ and $\mathrm{RO}_{2}$ ) during the night than during daytime, as expected. The increase of radical concentrations during daytime (06:0017:30 UTC) compared with the base model simulation varied, for alkenes concentrations of 50 and $100 \mathrm{ppt}$, between $15 \%$ and $26 \%$ for $\mathrm{OH}, 48 \%$ and $95 \%$ for $\mathrm{HO}_{2}$ and $44 \%$ and $92 \%$ for $\mathrm{RO}_{2}$. These results highlight the large influence of alkene ozonolysis on $\mathrm{RO}_{\mathrm{x}}$ concentrations and the importance of using a sensitive instrument to measure alkene species to study radical chemistry. However, this lack can explain neither the disagreement between the modelled and measured $\mathrm{OH}$ concentrations, nor the slight overestimation of simulated $\left(\mathrm{HO}_{2}+\mathrm{RO}_{2}\right)$ concentrations, since the addition of alkenes tends to increase the overestimation of the model for all radicals.

$\mathrm{NO}_{\mathrm{x}}$ measurement uncertainties can be high, especially at low levels (below a few ppb). Simulations have, thus, been performed varying constrained $\mathrm{NO}_{\mathrm{x}}$ concentrations by $10 \%$. Simulated $\mathrm{OH}, \mathrm{HO}_{2}$ and $\mathrm{RO}_{2}$ concentrations change by about $+4.5 /-4.6 \%,+12.8 /-11.7 \%$ and $+15 /-13.8 \%$ when constrained $\mathrm{NO}_{\mathrm{x}}$ concentrations are decreased or raised by $10 \%$ respectively. 

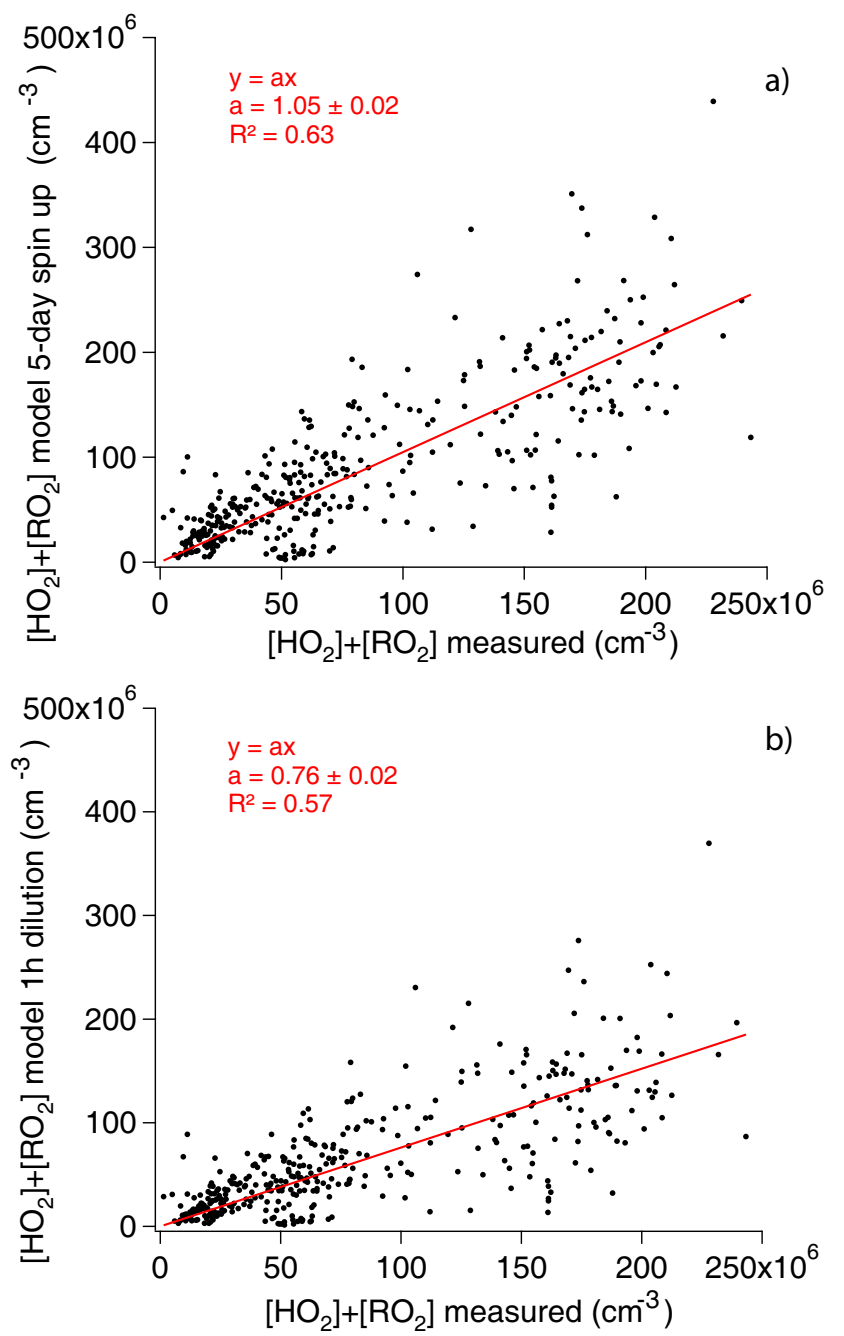

Fig. 12. Correlation between measured and modelled $\left(\mathrm{HO}_{2}+\mathrm{RO}_{2}\right)$ concentrations for the whole study period. The red line represents the linear regression forced through the origin, with a slope of 1.05 and a correlation coefficient $R^{2}$ of 0.63 for the 5-day spin up model approach (a) and with a slope of 0.76 and a correlation coefficient $R^{2}$ of 0.57 for the 1 h dilution model approach (b).

Quite high uncertainties are observed for species sampled by DNPH cartridges and then analysed by HPLC ( $25 \%$, see Table 1). Among them, the formaldehyde can represent an important source of radicals. Thus, simulations performed by varying constrained $\mathrm{HCHO}$ concentrations by $25 \%$ have been performed. This leads to differences for modelled $\mathrm{OH}$, $\mathrm{HO}_{2}$ and $\mathrm{RO}_{2}$ concentrations, respectively of $-3.5 /+3.3 \%$, $-5.8 /+5.8 \%$ and $-3.1 /+3.2 \%$ when $\mathrm{HCHO}$ concentrations are decreased or raised by $25 \%$.

Nitrous acid is one of the most important sources of $\mathrm{OH}$ in the atmosphere. The $2 \sigma$ relative uncertainties in our HONO measurements are about $12 \%$, which is not negligible. Thus, simulations were performed varying constrained HONO concentrations by $10 \%$. This resulted in modifications of $\mathrm{OH}$,

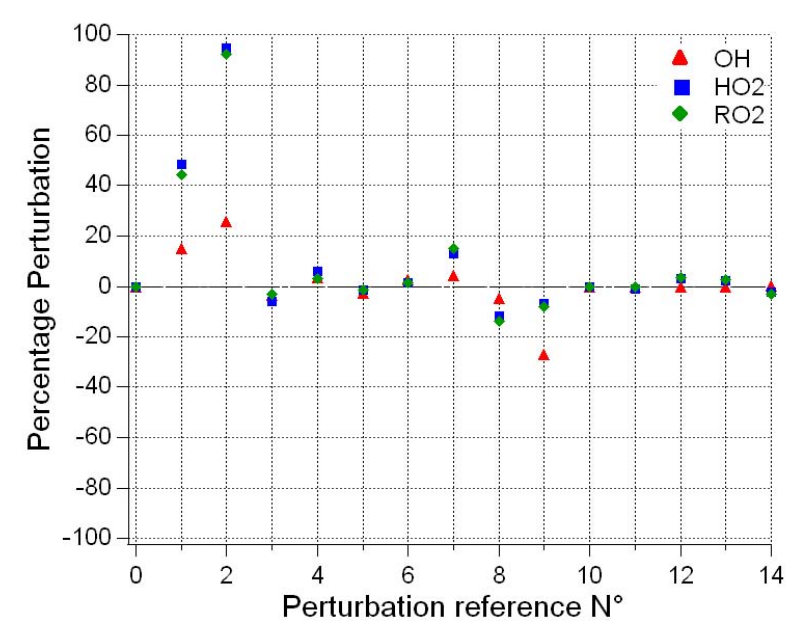

Fig. 13. Averaged percentage change in model $\mathrm{OH}$ (red triangles), $\mathrm{HO}_{2}$ (blue squares) and organic peroxy radicals $\mathrm{RO}_{2}$ (green diamonds) concentrations compared to the reference run for perturbations 1-14 (Table 3).

$\mathrm{HO}_{2}$ and $\mathrm{RO}_{2}$ concentrations, respectively of $-2.6 /+2.5 \%$, $-1.4 /+1.5 \%,-1.5 \% /+1.6 \%$ when HONO concentrations are decreased or raised by $10 \%$.

As an important number of photolysis frequencies are estimated in our model rather than being measured, uncertainties in their estimations cannot be excluded. To estimate the impact of such uncertainties on simulated radical concentration, simulations where $J\left(\mathrm{O}^{1} \mathrm{D}\right), J\left(\mathrm{NO}_{2}\right)$ and $J(\mathrm{HONO})$ have been decreased by $20 \%$ (which correspond to the estimated uncertainties in photolysis frequencies measurements) were performed. Other photolysis frequencies being estimated using the ratio between calculated and measured $J\left(\mathrm{O}^{1} \mathrm{D}\right)$ or $J\left(\mathrm{NO}_{2}\right)$ (see Sect. 3.2), they have been decreased, too. Simulated $\mathrm{OH}$ concentrations decreased by $27 \%$ whereas $\mathrm{HO}_{2}$ and $\mathrm{RO}_{2}$ are less affected, their predicted concentrations being decreased by $6.8 \%$ and $8.2 \%$. Thus, these uncertainties in photolysis frequencies could be one of the reasons for the 5-day spin up model overestimation compared with the radical measurements.

Simulations have been run adding an uptake of $\mathrm{HO}_{2}$ and $\mathrm{CH}_{3} \mathrm{O}_{2}$ on aerosol surface to the 5-day spin up model. The results of the model with the new scenarios compared with the measurements are shown in Fig. S5 in Supplement, as well as a discussion of these results. The changes observed in simulated radical concentrations are also listed in Table 3 and shown in Fig. 13. These changes were very low $(0.1-$ $0.4 \%$ for $\mathrm{OH}, 0.2-1.1 \%$ for $\mathrm{HO}_{2}$ and $0.1-0.4 \%$ for $\mathrm{RO}_{2}$ ). Under the conditions encountered during the MEGAPOLI summer campaign, the addition of $\mathrm{HO}_{2}$ and $\mathrm{CH}_{3} \mathrm{O}_{2}$ uptake on the aerosol surface by far cannot resolve the overestimation of simulated $\mathrm{OH}$ and $\left(\mathrm{HO}_{2}+\mathrm{RO}_{2}\right)$ concentrations, since the aerosol surface area was probably too small. 

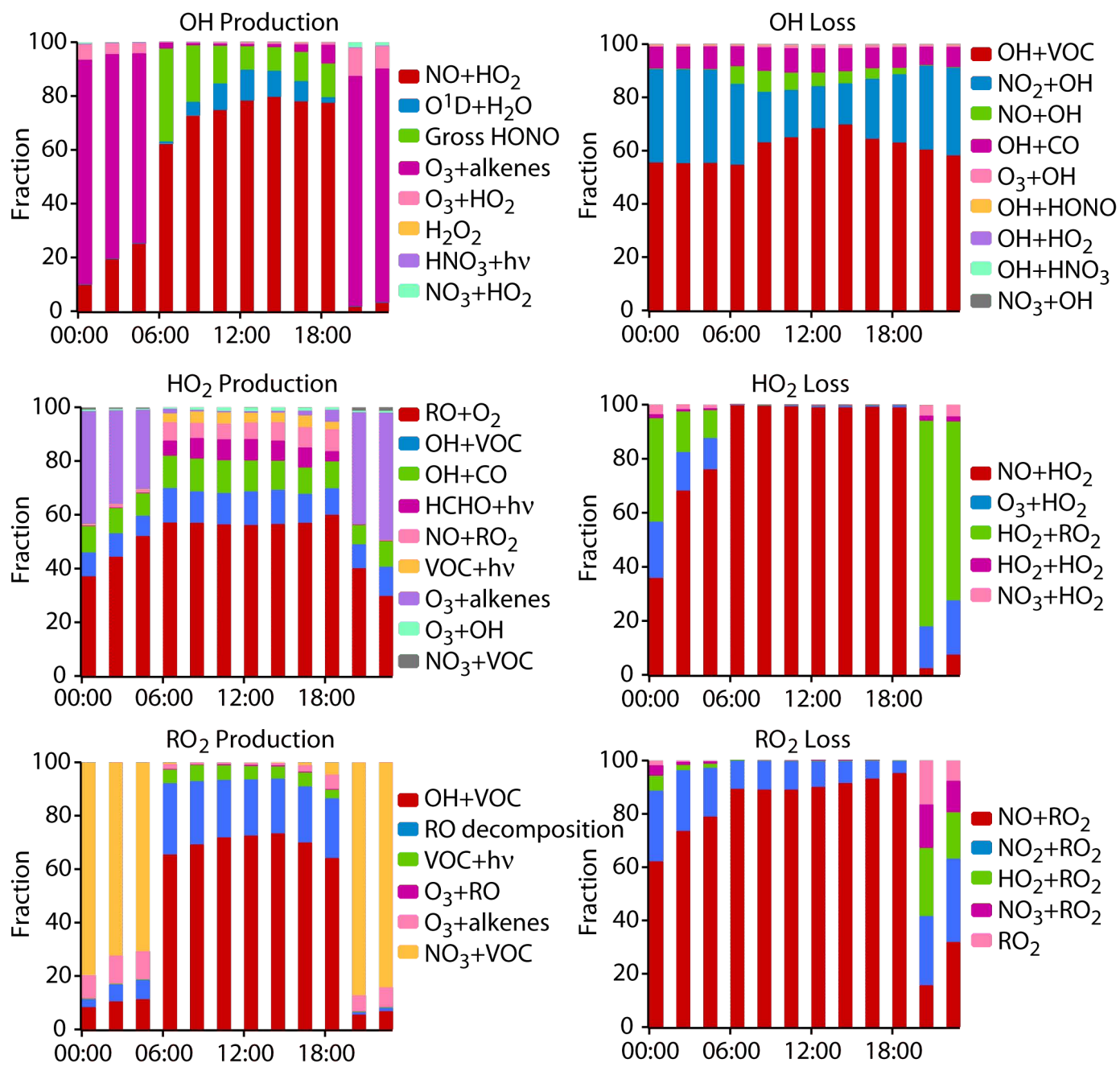

Fig. 14. Fraction of different processes involved in the production and loss of $\mathrm{OH}, \mathrm{HO}_{2}$ and $\mathrm{RO}_{2}$ for a one day simulation (5-day spin up model) constrained with mean diurnal campaign measurements of all species and parameters.

The addition of alkenes and the reduction of $\mathrm{NO}_{\mathrm{x}}$ concentrations lead to a significant rise of simulated $\mathrm{OH}, \mathrm{HO}_{2}$ and $\mathrm{RO}_{2}$ concentrations. The decrease of photolysis frequencies and the rise of $\mathrm{NO}_{\mathrm{x}}$ concentrations reduce significantly the simulated radical concentrations. On the contrary, the variations of $\mathrm{HONO}$ and $\mathrm{HCHO}$ concentrations, in the range of measurement uncertainties, lead to small changes in simulated radical concentrations. To summarize, these sensitivity tests have highlighted that uncertainties in simulated radical concentrations may partly come from measurement uncertainties of some species and parameters involved in radical initiation or termination processes and from the lack of anthropogenic alkene measurements.

\subsection{Radical budget analysis}

A radical budget analysis was carried out to investigate the key processes driving the radical initiation, propagation and termination during the MEGAPOLI summer campaign at the
SIRTA observatory. The results presented here are from a one-day simulation performed with the reference model version. To constrain the model, averaged observed diurnal campaign concentrations have been used.

Figure 14 represents the fraction of the different processes involved in the production and loss of $\mathrm{OH}, \mathrm{HO}_{2}$ and $\mathrm{RO}_{2}$. The $\mathrm{OH}$ production is mainly dominated by the $\mathrm{NO}+\mathrm{HO}_{2}$ reaction during the day $(60-80 \%)$, while reactions between $\mathrm{O}_{3}$ +alkenes and $\mathrm{O}_{3}+\mathrm{HO}_{2}$ dominate during the night $(70$ $80 \%$ for the reaction $\mathrm{O}_{3}+$ alkenes and $5-10 \%$ for the reaction $\mathrm{O}_{3}+\mathrm{HO}_{2}$ ). During the early morning, the second most important $\mathrm{OH}$ source just after the reaction between $\mathrm{NO}+\mathrm{HO}_{2}$ is $\mathrm{HONO}$ photolysis (contributing to more than $30 \%$ to $\mathrm{OH}$ production). The contribution of HONO photolysis then decreases to reach a minimum of approximately $10 \%$ between 12:00 and 14:00 UTC. This decrease is due to the diminishing of HONO concentrations observed in daytime hours because of its fast photolysis. The noontime $\mathrm{OH}$ 

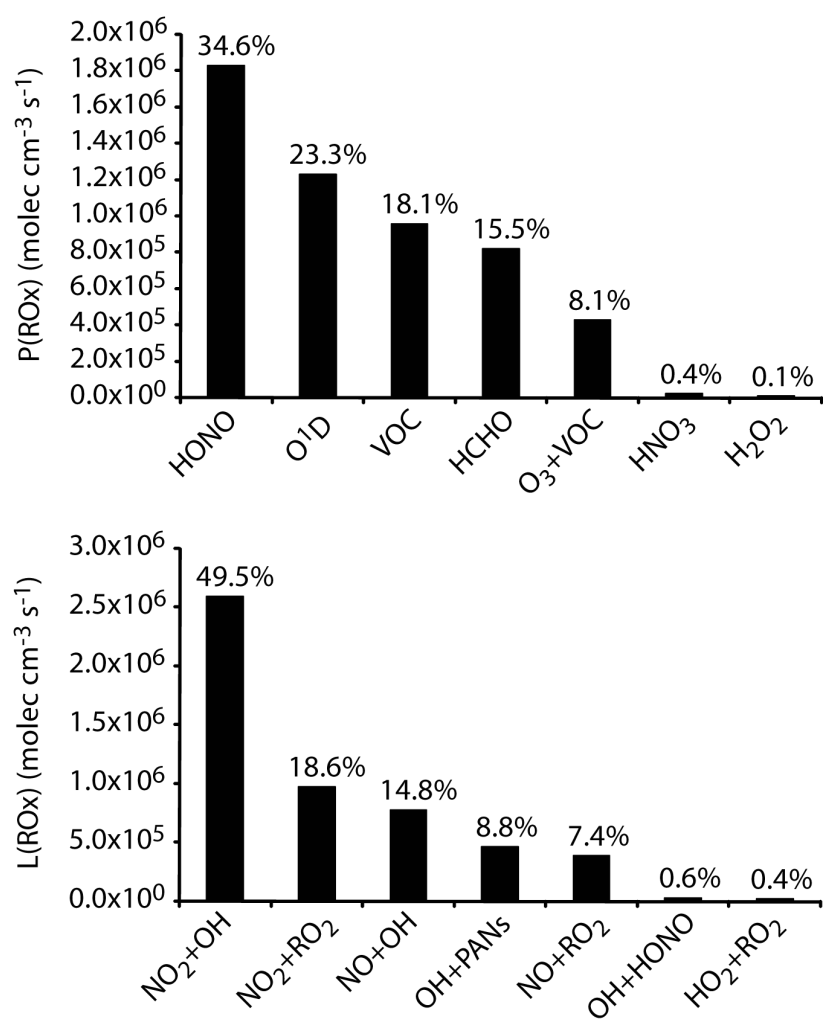

Fig. 15. Model calculated radicals initiation and termination rates averaged between 06:00 and 18:00 UTC for a one day simulation (5-day spin up model) constrained with mean daily campaign measurements of all species and parameters.

production through HONO photolysis stays significant and almost equivalent to the $\mathrm{OH}$ production through the reaction between $\mathrm{O}^{1} \mathrm{D}$ and water. Quite high $\mathrm{HONO}$ concentration of approximately hundred ppt remains throughout the day. The contribution of the reaction between $\mathrm{O}^{1} \mathrm{D}$ and water to $\mathrm{OH}$ production rises during morning hours and reaches its maximum (around $10 \%$ ) at 12:00 UTC with the maximum of photolysis. Other processes are negligible for $\mathrm{OH}$ production throughout the day.

$\mathrm{OH}$ sinks are dominated by reactions of $\mathrm{OH}$ with VOCs which contribute at a fraction higher than $55 \%$ all along the day and reach almost $65 \%$ during noontime hours. These reactions act as propagation reactions, leading mainly to $\mathrm{RO}_{2}$ formation ( $\sim 81 \%$ in average) but also directly to $\mathrm{HO}_{2}$ formation at a non negligible fraction ( $\sim 15 \%$ in average). The VOCs removing predominantly $\mathrm{OH}$ are isoprene, methylpropene, formaldehyde, methyl-vinyl-ketone, acetaldehyde and methyl-ethyl-ketone in this order of importance. The fraction of measured VOC responsible for the $\mathrm{OH}$ loss compared to the fraction of unmeasured species was quantified. Indeed, this fraction is comprised between 70 and $80 \%$ during daytime. This result is similar to that of Kato et al. (2011) who found that the contribution of the unidentified VOCs to
$\mathrm{OH}$ reactivity was about $22 \%$ of the total VOC for a suburban site located about $30 \mathrm{~km}$ from Tokyo city centre. The other main $\mathrm{OH}$ loss process is the reaction between $\mathrm{OH}$ and $\mathrm{NO}_{2}$ which leads to the formation of $\mathrm{HNO}_{3}$. This reaction is a radical termination, as the recycling of $\mathrm{OH}$ by $\mathrm{HNO}_{3}$ photolysis is very slow and $\mathrm{HNO}_{3}$ deposition is its main sink. The reaction between $\mathrm{OH}$ and $\mathrm{NO}_{2}$ represents more than $30 \%$ of $\mathrm{OH}$ loss during the night and almost $20 \%$ during the day. During sunlight hours, the reaction between $\mathrm{OH}$ and $\mathrm{NO}$ represents approximately $5 \%$ of $\mathrm{OH}$ loss processes. However, this reaction cannot be considered as a real radical sink since it leads to $\mathrm{HONO}$ formation which recycles $\mathrm{OH}$ by photolysis. The reactions between $\mathrm{OH}$ and $\mathrm{CO}$ lead to $\mathrm{HO}_{2}$ formation and thus to radical propagation and represents almost $10 \%$ of $\mathrm{OH}$ loss processes throughout the day. Other processes leading to $\mathrm{OH}$ loss are negligible all day long.

The production of $\mathrm{HO}_{2}$ is mainly dominated by the reaction of propagation between $\mathrm{RO}$ and $\mathrm{O}_{2}$ with a contribution to total $\mathrm{HO}_{2}$ production representing of more than $40 \%$ all day long and reaching $50 \%$ during daytime. The contribution to total $\mathrm{HO}_{2}$ production of other reactions of propagation through the $\mathrm{OH}$ to $\mathrm{HO}_{2}$ pathway represents approximately $20 \%$ all along the day. These propagation reactions are the reaction of $\mathrm{OH}$ with $\mathrm{CO}, \mathrm{O}_{3}$ and different VOCs. Another propagation pathway is the reaction between $\mathrm{RO}_{2}$ and $\mathrm{NO}$ which represents 6-7\% of the total $\mathrm{HO}_{2}$ production during daytime hours (between 06:00 and 18:00 UTC) but is almost inexistent during night time. During daytime, $\mathrm{HO}_{2}$ initiation is nearly entirely due to the photolysis of $\mathrm{HCHO}$ and VOCs (other aldehydes and ketones). The contribution to total $\mathrm{HO}_{2}$ production from these reactions is $10-20 \%$ with maximum around noon. The HCHO photolysis accounts for almost twice the other aldehydes and ketones photolysis in terms of $\mathrm{HO}_{2}$ production.

During the day, the $\mathrm{HO}_{2}$ loss is almost exclusively due to its reaction with $\mathrm{NO}$ which leads to the formation of $\mathrm{OH}$ and $\mathrm{NO}_{2}$. During the night, $\mathrm{NO}$ concentrations decrease and self radical reactions become fast enough to compete with the reaction between $\mathrm{HO}_{2}$ and $\mathrm{NO}$ and to play a role in $\mathrm{HO}_{2}$ loss. Indeed, during the late evening, the reaction between $\mathrm{HO}_{2}$ and $\mathrm{RO}_{2}$ reaches a contribution of almost $80 \%$ of the $\mathrm{HO}_{2}$ loss while the contribution of self reaction of $\mathrm{HO}_{2}$ remains very low.

During the day, the main $\mathrm{RO}_{2}$ production is due to the reaction of VOCs with $\mathrm{OH}$. These reactions account for 60 to $70 \%$ of $\mathrm{RO}_{2}$ production with a maximum of the contribution reached at the maximum of photolysis. The second main daily $\mathrm{RO}_{2}$ production is due to the $\mathrm{RO}$ decomposition which contributes up to $20 \%$ all along the daytime hours. Thus, during sunlight hours $\mathrm{RO}_{2}$ production is dominated by propagation reactions to around $80-90 \%$. The remaining $\mathrm{RO}_{2}$ production during the day is due to initiation reactions mainly dominated by VOC (aldehydes and ketones) photolysis between 3 and $5 \%$ of total $\mathrm{RO}_{2}$ production. During the night the $\mathrm{RO}_{2}$ production is dominated by the reaction of the $\mathrm{NO}_{3}$ 


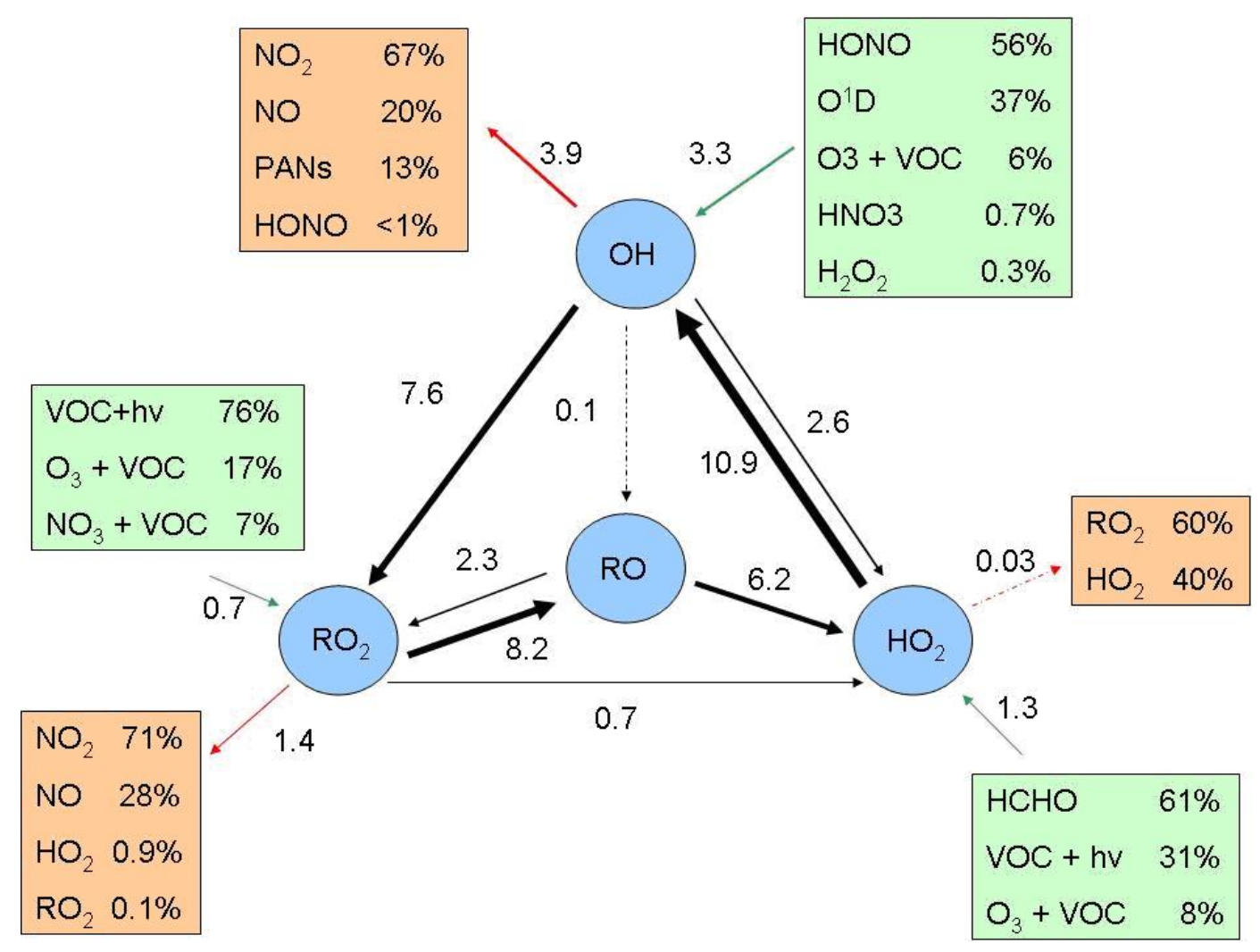

Fig. 16. Rate of radical initiation (green arrows), propagation (black arrows) and termination (red arrows) averaged between 06:00 and 18:00 UTC. These calculations are from a one day simulation (5-day spin up model) constrained with mean diurnal campaign measurements of all species and parameters. The numbers represent the rates in $10^{6}$ molecule $\mathrm{cm}^{-3} \mathrm{~s}^{-1}$.

radical with VOCs accounting for $70-90 \%$ of the $\mathrm{RO}_{2}$ production.

The $\mathrm{RO}_{2}$ loss is dominated by the reactions between $\mathrm{RO}_{2}$ and NO. These reactions account for 90 to $95 \%$ of total $\mathrm{RO}_{2}$ loss during the day and lead to the formation of RO, corresponding to propagation reactions, or of organic nitrates, corresponding to a radical sink. During the day the remaining $\mathrm{RO}_{2}$ loss (approximately $5-10 \%$ ) is due to the reaction between $\mathrm{RO}_{2}$ and $\mathrm{NO}_{2}$. These reactions lead mainly to the formation of PANs. During the night, as for $\mathrm{HO}_{2}$, radical self reactions become fast enough to compete with other reactions and play a role in $\mathrm{RO}_{2}$ loss.

Figure 15 presents the radical initiation and termination rates for different reactions, averaged over daytime hours (06:00-18:00 UTC), as well as their contribution in the total radical initiation and termination. In other words, it presents sources and sinks for the $\mathrm{RO}_{\mathrm{x}}=\mathrm{OH}+\mathrm{HO}_{2}+\mathrm{RO}+\mathrm{RO}_{2}$ budget. As it has been observed in many recent studies in both urban or rural environments (Ren et al., 2003b; Kleffmann et al., 2005; Ren et al. 2006; Dusanter et al., 2009; Elshorbany et al., 2009), HONO photolysis is a major radical source all over the day and not just during morning hours. Considering gross HONO photolysis, it accounts for approximately $35 \%$ of total radical initiation, which is comparable to what $\mathrm{Du}$ - santer et al. (2009) found in Mexico City (34.5\%). However, subtracting the reaction between $\mathrm{OH}$ and $\mathrm{NO}$ to consider the net HONO source, its contribution to radical initiation falls to $23 \%$ which still represents an important radical initiation pathway all over the day. The other reactions contributing to radical initiation are the reaction between $\mathrm{O}\left({ }^{1} \mathrm{D}\right)$ and water $(23.3 \%)$, photolysis of aldehydes (other than $\mathrm{HCHO}$ ) and ketones $(18.1 \%)$, HCHO photolysis $(15.5 \%)$ and alkenes ozonolysis $(8.1 \%)$. However, it is important to note that the radical initiation via aldehydes (other than $\mathrm{HCHO}$ ) and ketones photolysis is only due to approximately 30 to $50 \%$ of measured species, the remaining fraction being unmeasured species especially dicarbonyls which were formed in the model. Thus, an important error can be made in the estimation of this radical initiation pathway. Moreover, simulations performed with the $1 \mathrm{~h}$ dilution model version (see Sect. 3.2), show results different from the 5-day spin up model version concerning radical initiation. Indeed, the radical initiation via aldehyde (other than $\mathrm{HCHO}$ ) and ketones photolysis is less important and represents only $9.5 \%$ of total radical initiation on a daily basis, behind HONO photolysis $(40 \%)$, reaction between $\mathrm{O}\left({ }^{1} \mathrm{D}\right)$ and water $(27 \%)$ and HCHO photolysis (17\%). The radical termination appears to be largely dominated by the reaction between $\mathrm{OH}$ and $\mathrm{NO}_{\mathrm{x}}$, 
Table 3. $\mathrm{OH}, \mathrm{HO}_{2}$ and sum of organic peroxy radicals $\mathrm{RO}_{2}$ sensitivities to model constraints and parameters. Sensitivity tests have been conducted over the full campaign period.

\begin{tabular}{|c|c|c|c|c|}
\hline \multirow[t]{2}{*}{ Number } & \multirow[t]{2}{*}{ Perturbation } & \multicolumn{3}{|c|}{ Percentage Perturbation in } \\
\hline & & $\mathrm{OH}$ & $\mathrm{HO}_{2}$ & $\mathrm{RO}_{2}$ \\
\hline 0 & Reference run & 0 & 0 & 0 \\
\hline 1 & addition of alkenes at $50 \mathrm{ppt}$ & 14.9 & 48.3 & 44.4 \\
\hline 2 & addition of alkenes at $100 \mathrm{ppt}$ & 25.9 & 94.5 & 92.1 \\
\hline 3 & $\mathrm{HCHO}-25 \%$ & -3.5 & -5.8 & -3.1 \\
\hline 4 & $\mathrm{HCHO}+25 \%$ & 3.3 & 5.8 & 3.2 \\
\hline 5 & HONO $-10 \%$ & -2.6 & -1.4 & -1.5 \\
\hline 6 & $\mathrm{HONO}+10 \%$ & 2.5 & 1.5 & 1.6 \\
\hline 7 & $\mathrm{NO}_{\mathrm{X}}-10 \%$ & 4.5 & 12.8 & 15 \\
\hline 8 & $\mathrm{NO}_{\mathrm{x}}+10 \%$ & -4.6 & -11.7 & -13.8 \\
\hline 9 & $J \times 0.8$ & -27 & -6.8 & -8.2 \\
\hline 10 & $\begin{array}{l}\text { addition of } \mathrm{HO}_{\mathrm{x}} \text { uptake on aerosols with } \\
\gamma_{\mathrm{HO}_{2}}=0.2\end{array}$ & -0.1 & -0.2 & -0.1 \\
\hline 11 & addition of $\mathrm{HO}_{\mathrm{x}}$ uptake on aerosols with & -0.4 & -1.1 & -0.4 \\
\hline 12 & $\begin{array}{l}\text { deposition of other species than those listed } \\
\text { in Sect. } 3.2 \text { set to } 0 \mathrm{~cm} \mathrm{~s}^{-1}\end{array}$ & -0.2 & 3.1 & 3.6 \\
\hline 13 & $\begin{array}{l}\text { deposition of other species than those listed } \\
\text { in Sect. } 3.2 \text { set to } 0.1 \mathrm{~cm} \mathrm{~s}^{-1}\end{array}$ & -0.1 & 2.1 & 2.5 \\
\hline 14 & $\begin{array}{l}\text { deposition of other species than those listed } \\
\text { in Sect. } 3.2 \text { set to } 2 \mathrm{~cm} \mathrm{~s}^{-1}\end{array}$ & 0.3 & -2.4 & -2.9 \\
\hline
\end{tabular}

the reaction between $\mathrm{RO}_{2}$ and $\mathrm{NO}_{\mathrm{x}}$ and the reaction between $\mathrm{OH}$ and some PANs. It also appears that, during the day, the self reactions between radicals $\left(\mathrm{HO}_{2}+\mathrm{HO}_{2}, \mathrm{HO}_{2}+\mathrm{RO}_{2}\right.$ and $\mathrm{RO}_{2}+\mathrm{RO}_{2}$ ) are negligible because of the quite high $\mathrm{NO}_{\mathrm{x}}$ level at Palaiseau during the MEGAPOLI summer campaign. The importance of termination reactions between $\mathrm{RO}_{2}$ and $\mathrm{NO}$ or $\mathrm{NO}_{2}$, not taken into account in PSS calculations, can explain the incapacity of PSS calculations to reproduce $\mathrm{OH}$ concentrations while better results are observed for model calculations, where these reactions are included.

Daily averages (06:00-18:00 UTC) of initiation, propagation and termination rates are shown in Fig. 16. Averaged initiation and termination rates over the daytime hours are in balance around $5.3 \times 10^{6}$ molecule $\mathrm{cm}^{-3} \mathrm{~s}^{-1}$. These rates are approximately five times lower than the initiation and termination rates observed during MCMA-2006 by Dusanter et al. (2009) in the centre of Mexico City. These observed differences are mainly due to far less polluted conditions, characterised by lower $\mathrm{NO}_{\mathrm{x}}$ and VOCs levels, and less intense sunlight at SIRTA. However, we encountered closer total initiation and termination rates as Kanaya et al. (2012) in Jülich, Germany, in July 2005, where the total initiation rate in the period 12:00-15:00 UTC was comprised around $1.5 \times 10^{7}$ molecule $\mathrm{cm}^{-3} \mathrm{~s}^{-1}$, while we found approximately $1.0 \times 10^{7}$ molecule $\mathrm{cm}^{-3} \mathrm{~s}^{-1}$ total initiation rate in the period 12:00-16:00 UTC. This corresponds to rather unpolluted conditions at the SIRTA site under the campaign con- ditions when most often oceanic air masses with little urban pollution were sampled.

\section{Conclusions}

The MEGAPOLI summer campaign provides an opportunity to assess our current knowledge of atmospheric gas chemistry and to provide a description of radical cycling reactions in a suburban environment. This was possible thanks to the large number of gaseous species and environmental parameters measured during this experiment concurrently with $\mathrm{OH}$ and $\left(\mathrm{HO}_{2}+\mathrm{RO}_{2}\right)$ measurements. $\mathrm{OH}$ and $\left(\mathrm{HO}_{2}+\mathrm{RO}_{2}\right)$ were measured during the campaign and showed typical diurnal profiles with daytime maxima around solar noon of $(3.5-10.6) \times 10^{6}$ and $(1.1-3.6) \times 10^{8}$ molecule $\mathrm{cm}^{-3}$, respectively.

$\mathrm{OH}$ Photo Stationary State (PSS) calculations were performed and compared with $\mathrm{OH}$ measurements. This comparison shows a systematic overestimation of the calculation especially at low $\mathrm{NO}_{\mathrm{x}}$ levels $(<5 \mathrm{ppb})$. Then, a photochemical zero-dimensional box model, incorporating the Master Chemical Mechanism (MCM), was constrained by all measured parameters. This model was used to calculate radical concentrations $\left(\mathrm{OH}\right.$ and $\left.\left(\mathrm{HO}_{2}+\mathrm{RO}_{2}\right)\right)$ as well as their rates of initiation, propagation and termination. One of the challenges encountered with such a method was to estimate the unconstrained secondary organic compounds. To do so, several versions of the model were tested and compared with 
a reference model version. While the different approaches led to slight modifications of estimated $\mathrm{OH}$ concentrations (0.4 to $6.0 \%$ ), more important changes were observed for estimated $\mathrm{HO}_{2}$ and $\mathrm{RO}_{2}$ concentrations (16 to $31 \%$ for $\mathrm{HO}_{2}$ and 23 to $39 \%$ for $\mathrm{RO}_{2}$ ) excepted for the $2 \mathrm{~h}$ dilution model version where no significant differences were observed compared with the base case scenario $(0.4,0.9$ and $2.7 \%$ for $\mathrm{OH}$, $\mathrm{HO}_{2}$ and $\mathrm{RO}_{2}$ respectively).

Based on the reference model simulations, the modelled $\mathrm{OH}$ and $\left(\mathrm{HO}_{2}+\mathrm{RO}_{2}\right)$ concentrations were overestimated on average by factors of 1.12 and 1.05 , respectively, which is pretty satisfactory given measurement uncertainties, and similar to some previous studies in suburban or remote environment. Based on the $1 \mathrm{~h}$ dilution simulations, $\mathrm{OH}$ concentrations were still overestimated (factor of 1.2) while $\left(\mathrm{HO}_{2}+\mathrm{RO}_{2}\right)$ concentrations were in average underestimated by a factor of 0.76 . The approach used in the $1 \mathrm{~h}$ dilution model scenario led to lower formation of secondary VOCs and therefore to lower $\mathrm{OH}$ reactivity, but also to a decrease of radicals sources through OVOC (Oxygenated VOC) photolysis, compared with the reference scenario. This lower amount of secondary VOCs leads to underestimation of $\left(\mathrm{HO}_{2}+\mathrm{RO}_{2}\right)$ concentrations while the overestimation of $\mathrm{OH}$ concentrations became slightly worse. These results point out the difficulty and the importance of the way this unmeasured secondary material is estimated by the model. Therefore, we advise to perform measurements of secondary VOCs as exhaustive as possible, especially for multifunctional ones in future campaigns. However, the use of the different versions of the model presented in this study allows encompassing the concentration of non measured VOCs and therefore their influence on radical budget.

The fact that modelled radical concentrations calculated with the reference model version were slightly overestimated indicates that some processes might be missing or might not be well estimated in the model. Therefore, the impact of the addition of $\mathrm{HO}_{\mathrm{x}}$ uptake on aerosol surfaces in the model has been investigated, showing changes in modelled radical concentrations not important enough to explain the discrepancies between the model and the measurements. Other sensitivity tests had shown high model sensitivity to photolysis rates, $\mathrm{NO}_{\mathrm{x}}$ and alkenes. Moreover, the sensitivity tests conducted in this study highlight the fact that uncertainties in model results could come from uncertainties in the measurement of some constrained parameters and species, or from the lack of anthropogenic alkenes measurements.

The analysis of the radical budget indicated that radical initiation resulted from several photolytic processes during the MEGAPOLI summer campaign. During daytime hours (06:00-18:00 UTC), the model predicted that the photolysis of HONO $(34.6 \%)$, the reaction between $\mathrm{O}\left({ }^{1} \mathrm{D}\right)$ and water $(23.3 \%)$, the photolysis of aldehydes (other than $\mathrm{HCHO}$ ) and ketones $(18.1 \%)$ and the photolysis of $\mathrm{HCHO}(15.5 \%)$ were the main sources of $\mathrm{RO}_{\mathrm{x}}$. However, the high contribution of the photolysis of aldehydes (other than HCHO) and ketones found by the model needs to be balanced by the fact that a high proportion of estimated secondary VOCs were involved in this radical production pathway (more than 50\%). Furthermore, the importance of the secondary VOC photolysis pathway was lowered when other model versions for the unconstrained species calculation were used. Production of $\mathrm{OH}$ from alkenes ozonolysis was found to be of minor importance $(8.1 \%)$ considering the absence of linear and branched alkenes of anthropogenic origin in model constraints because of their very low concentration levels during the MEGAPOLI summer campaign.

The analysis of the radical budget highlights also the importance of reactions between $\mathrm{RO}_{2}$ and $\mathrm{NO}_{\mathrm{x}}$ as radical termination reactions (approximately $26 \%$ of total radical loss processes). These reactions were not taken into account in PSS calculations. This can explain the better agreement between the modelled and measured radical concentrations compared to the agreement between $\mathrm{OH}$ concentrations measured and estimated with PSS calculations. The total initiation and termination rates were in balance, around $5.3 \times 10^{6}$ molecule $\mathrm{cm}^{-3} \mathrm{~s}^{-1}$, and similar to other ones found during previous studies in suburban or remote areas but far lower than other ones found in previous urban field campaigns.

\section{Supplementary material related to this article is available online at: http://www.atmos-chem-phys.net/12/ 11951/2012/acp-12-11951-2012-supplement.pdf.}

Acknowledgements. The research leading to these results has received funding from the European Union's Seventh Framework Programme FP/2007-2011 under grant agreement no. 212520.

The authors also acknowledge the ANR through the MEGAPOLI PARIS and INSU/ LEFE through the MEGAPOLI France project for their financial support. Moreover, the research leading to these results has been carried out in the framework of a thesis supported by CNRS grant.

The authors also want to thank Eurochamp-2 (EU-FP7 grant agreement no. 228335) for supporting intercalibration exercises, Birger Bohn, Forschungszentrum Jülich, Germany, for the calibration of the $J\left(\mathrm{NO}_{2}\right)$ filter radiometer and the SAOZ network for their $\mathrm{O}_{3}$ column data. Moreover, the authors acknowledge the team from the SIRTA observatory for their technical support. Acknowledgments are extended to J-C. Dupont for providing the boundary layer height retrievals used in this study and to R. Sarda and J. Nicolas for CO measurements. A. Stohl and S. Eckhardt are also thankfully acknowledged for providing the retroplume calculations.

Edited by: P. Monks 


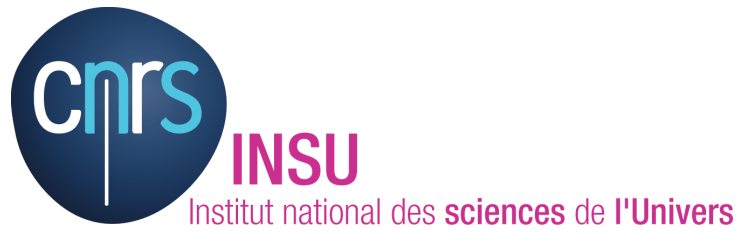

The publication of this article is financed by CNRS-INSU.

\section{References}

Acker, K., Moller, D., Wieprecht, W., Meixner, F. X., Bohn, B., Gilge, S., Plass-Dulmer, C., and Berresheim, H.: Strong daytime production of $\mathrm{OH}$ from $\mathrm{HNO} 2$ at a rural mountain site, Geophys. Res. Lett., 33, L02809, doi:10.1029/2005GL024643, 2006.

Afif, C., Jambert, C., Colomb, A., Eyglunent, G., Borbon, A., Daële, V., Doussin, J. F., and Perros, P. E.: NitroMAC: an instrument for the measurement of HONO, Intercomparison with LOPAP, Water Air. Soil. Poll., submitted, 2012

Ait-Helal, W., Borbon A., Sauvage S., De Gouw, J. A., Colomb A., Beekmann, M., Afif C., Durand-Jolibois, R., Fronval, I., Grand, N., Leonardis T., Michoud V., Miet K., Perrier, S., Siour G., Zapf, P., Doussin J. F., Lopez M., Gros V., Freutel F., Schneider J., Crippa M., Prevot A. S. H., and Baltensperger U., N. Locoge : I/VOC in sub-urban Paris: variability, origin and importance in SOA formation, Atmos. Chem. Phys. Discuss., in preparation, 2012.

Atkinson, R., Baulch, D. L., Cox, R. A., Crowley, J. N., Hampson, R. F., Hynes, R. G., Jenkin, M. E., Rossi, M. J., and Troe, J.: Evaluated kinetic and photochemical data for atmospheric chemistry: Volume $\mathrm{I}-$ gas phase reactions of $\mathrm{O}_{\mathrm{x}}, \mathrm{HO}_{\mathrm{x}}, \mathrm{NO}_{\mathrm{x}}$ and $\mathrm{SO}_{\mathrm{x}}$ species, Atmos. Chem. Phys., 4, 1461-1738, doi:10.5194/acp-41461-2004, 2004.

Aumont, B., Chervier, F., and Laval, S.: Contribution of HONO sources to the $\mathrm{NO}_{\mathrm{x}} / \mathrm{HO}_{\mathrm{x}} / \mathrm{O}_{3}$ chemistry in the polluted boundary layer, Atmos. Environ., 37, 487-498, 2003.

Berresheim, H., Elste, T., Plass-Dulmer, C., Eisele, F. L., and Tanner, D. J.: Chemical ionization mass spectrometer for long-term measurements of atmospheric $\mathrm{OH}$ and $\mathrm{H}_{2} \mathrm{SO}_{4}$, Int. J. Mass. Spectrom, 202, 91-109, 2000.

Bey, I., Aumont, B., and Toupance, G.: A modeling study of the nighttime radical chemistry in the lower continental troposphere 2. Origin and evolution of $\mathrm{HO}_{\mathrm{x}}$, J. Geophys. Res., 106, 999110001, 2001.

Bloss, C., Wagner, V., Jenkin, M. E., Volkamer, R., Bloss, W. J., Lee, J. D., Heard, D. E., Wirtz, K., Martin-Reviejo, M., Rea, G., Wenger, J. C., and Pilling, M. J.: Development of a detailed chemical mechanism (MCMv3.1) for the atmospheric oxidation of aromatic hydrocarbons, Atmos. Chem. Phys., 5, 641-664, doi:10.5194/acp-5-641-2005, 2005.

Bloss, W. J., Camredon, M., Lee, J. D., Heard, D. E., Plane, J. M. C., Saiz-Lopez, A., Bauguitte, S. J.-B., Salmon, R. A., and Jones, A. E.: Coupling of $\mathrm{HO}_{\mathrm{x}}, \mathrm{NO}_{\mathrm{x}}$ and halogen chemistry in the antarctic boundary layer, Atmos. Chem. Phys., 10, 1018710209, doi:10.5194/acp-10-10187-2010, 2010.

Brasseur, G. P., Hauglustaine, D. A., Walters, S., Rasch, P. J., Muller, J. F., Granier, C., and Tie, X. X.: MOZART, a global chemical transport model for ozone and related chemical trac- ers 1. Model description, J. Geophys. Res., 103, 28265-28289, 1998.

Calvert, J. G., Atkinson, R., Kerr, J. A., Madronich, S., Moortgat, G. K., Wallington, T. J., and Yarwood, G.: The Mechanisms of Atmospheric Oxidation of the Alkenes, Oxford University Press, Oxford, 2000

Carslaw, N., Creasey, D. J., Heard, D. E., Lewis, A. C., McQuaid, J. B., Pilling, M. J., Monks, P. S., Bandy, B. J., and Penkett, S. A.: Modeling $\mathrm{OH}, \mathrm{HO}_{2}$, and $\mathrm{RO}_{2}$ radicals in the marine boundary layer -1 . Model construction and comparison with field measurements, J. Geophys. Res., 104, 30241-30255, 1999a.

Carslaw, N., Jacobs, P. J., and Pilling, M. J.: Modeling OH, $\mathrm{HO}_{2}$ and $\mathrm{RO}_{2}$ radicals in the marine boundary layer 2. Mechanism reduction and uncertainty analysis, J. Geophys. Res., 104, $30257-$ 30273, 1999b.

Carslaw, N., Creasey, D. J., Harrison, D., Heard, D. E., Hunter, M. C., Jacobs, P. J., Jenkin, M. E., Lee, J. D., Lewis, A. C., Pilling, M. J., Saunders, S. M., and Seakins, P. W.: $\mathrm{OH}$ and $\mathrm{HO}_{2}$ radical chemistry in a forested region of north-western Greece, Atmos. Environ., 35, 4725-4737, 2001.

Carslaw, N., Creasey, D. J., Heard, D. E., Jacobs, P. J., Lee, J. D., Lewis, A. C., McQuaid, J. B., Pilling, M. J., Bauguitte, S., Penkett, S. A., Monks, P. S., and Salisbury, G.: Eastern Atlantic Spring Experiment 1997 (EASE97) - 2. Comparisons of model concentrations of $\mathrm{OH}, \mathrm{HO} 2$, and $\mathrm{RO} 2$ with measurements, J. Geophys. Res., 107, D14, 4190, 2002.

Carter, W. P. L.: Development of a condensed SAPRC-07 chemical mechanism, Atmos. Environ., 44, 5336-5345, 2010.

Cotte, H.: Développement d'une technique spectroradiométrique pour la détermination expérimentale des fréquences de photolyse troposphérique: Application au bilan photostationnaire de radicaux libres des campagnes FieldVOC., U.F.R de Chimie, Université Paris VII - Denis Diderot, Paris, 52-118, 1995.

Creasey, D. J., Heard, D. E., and Lee, J. D.: $\mathrm{OH}$ and $\mathrm{HO}_{2}$ measurements in a forested region of north-western Greece, Atmos. Environ., 35, 4713-4724, 2001.

Creasey, D. J., Heard, D. E., and Lee, J. D.: Eastern Atlantic Spring Experiment 1997 (EASE97) 1. Measurements of $\mathrm{OH}$ and $\mathrm{HO}_{2}$ concentrations at Mace Head, Ireland, J. Geophys. Res., 107, D10, 4091, 2002.

Derwent, R. G.: The influence of human activities on the distribution of hydroxyl radicals in the troposphere, Philos. T. R. Soc. A, 354, 501-531, 1996.

Detournay, A., Sauvage, S., Locoge, N., Gaudion, V., Leonardis, T., Fronval, I., Kaluzny, P., and Galloo, J. C.: Development of a sampling method for the simultaneous monitoring of straightchain alkanes, straight-chain saturated carbonyl compounds and monoterpenes in remote areas, J. Environ. Monitor., 13, 983990, 2011.

Donahue, N. M., Kroll, J. H., Anderson, J. G., and Demerjian, K. L.: Direct observation of $\mathrm{OH}$ production from the ozonolysis of olefins, Geophys. Res. Lett., 25, 59-62, 1998.

Dunlea, E. J. and Ravishankara, A. R.: Measurement of the rate coefficient for the reaction of $\mathrm{O}((1) \mathrm{D})$ with $\mathrm{H}(2) \mathrm{O}$ and re-evaluation of the atmospheric $\mathrm{OH}$ production rate, Phys. Chem. Chem. Phys., 6, 3333-3340, 2004a.

Dunlea, E. J. and Ravishankara, A. R.: Kinetic studies of the reactions of $\mathrm{O}((1) \mathrm{D})$ with several atmospheric molecules, Phys. Chem. Chem. Phys., 6, 2152-2161, 2004b. 
Dusanter, S., Vimal, D., Stevens, P. S., Volkamer, R., Molina, L. T., Baker, A., Meinardi, S., Blake, D., Sheehy, P., Merten, A., Zhang, R., Zheng, J., Fortner, E. C., Junkermann, W., Dubey, M., Rahn, T., Eichinger, B., Lewandowski, P., Prueger, J., and Holder, $\mathrm{H} .:$ Measurements of $\mathrm{OH}$ and $\mathrm{HO} 2$ concentrations during the MCMA-2006 field campaign - Part 2: Model comparison and radical budget, Atmos. Chem. Phys., 9, 6655-6675, doi:10.5194/acp-9-6655-2009, 2009.

Elshorbany, Y. F., Kurtenbach, R., Wiesen, P., Lissi, E., Rubio, M., Villena, G., Gramsch, E., Rickard, A. R., Pilling, M. J., and Kleffmann, J.: Oxidation capacity of the city air of Santiago, Chile, Atmos. Chem. Phys., 9, 2257-2273, doi:10.5194/acp-92257-2009, 2009.

Eisele, F. L. and Tanner, D. J.: Ion-assisted tropospheric OH measurements, J. Geophys. Res., 96, 9295-9308, 1991.

Eisele, F. L., Mount, G. H., Tanner, D., Jefferson, A., Shetter, R., Harder, J. W., and Williams, E. J.: Understanding the production and interconversion of the hydroxyl radical during the Tropospheric OH Photochemistry Experiment, J. Geophys. Res., 102, 6457-6465, 1997.

Emmerson, K. M., Carslaw, N., Carpenter, L. J., Heard, D. E., Lee, J. D., and Pilling, M. J.: Urban atmospheric chemistry during the PUMA campaign 1: Comparison of modelled $\mathrm{OH}$ and $\mathrm{HO}_{2}$ concentrations with measurements, J. Atmos. Chem., 52, 143 164, 2005a.

Emmerson, K. M., Carslaw, N., and Pilling, M. J.: Urban atmospheric chemistry during the PUMA campaign 2: Radical budgets for $\mathrm{OH}, \mathrm{HO}_{2}$ and $\mathrm{RO}_{2}$, J. Atmos. Chem., 52, 165-183, $2005 b$.

Emmerson, K. M., Carslaw, N., Carslaw, D. C., Lee, J. D., McFiggans, G., Bloss, W. J., Gravestock, T., Heard, D. E., Hopkins, J., Ingham, T., Pilling, M. J., Smith, S. C., Jacob, M., and Monks, P. S.: Free radical modelling studies during the UK TORCH Campaign in Summer 2003, Atmos. Chem. Phys., 7, 167-181, doi:10.5194/acp-7-167-2007, 2007.

Finlayson-Pitts, B. J. and Pitts, J. N.: Chemistry of the upper and lower atmosphere, Academic Press, San Diego, 2000.

Freutel, F., Schneider, J., Drewnick, F., von der Weiden-Reinmüller, S.-L., Crippa, M., Prévôt, A. S. H., Baltensperger, U., Poulain, L., Wiedensohler, A., Sciare, J., Sarda-Estève, R., Burkhart, J. F., Eckhardt, S., Stohl, A., Gros, V., Colomb, A., Michoud, V., Doussin, J. F., Borbon, A., Haeffelin, M., Morille, Y., Beekmann, M., and Borrmann, S.: Aerosol particle measurements at three stationary sites in the megacity of Paris during summer 2009: meteorology and air mass origin dominate aerosol particle composition and size distribution, Atmos. Chem. Phys. Discuss., 12, 22199-22268, doi:10.5194/acpd-12-22199-2012, 2012.

Fuchs, H., Bohn, B., Hofzumahaus, A., Holland, F., Lu, K. D., Nehr, S., Rohrer, F., and Wahner, A.: Detection of $\mathrm{HO}_{2}$ by laserinduced fluorescence: calibration and interferences from $\mathrm{RO}_{2}$ radicals, Atmos. Meas. Tech., 4, 1209-1225, doi:10.5194/amt4-1209-2011, 2011.

George, L. A., Hard, T. M., and O'Brien, R. J.: Measurement of free radicals $\mathrm{OH}$ and $\mathrm{HO}_{2}$ in Los Angeles smog, J. Geophys. Res., 104, 11643-11655, 1999.

Geyer, A., Bachmann, K., Hofzumahaus, A., Holland, F., Konrad, S., Klupfel, T., Patz, H. W., Perner, D., Mihelcic, D., Schafer, H. J., Volz-Thomas, A., and Platt, U.: Nighttime formation of peroxy and hydroxyl radicals during the BERLIOZ campaign: Ob- servations and modeling studies, J. Geophys. Res.-Atmos., 108, doi:10.1029/2001jd000656, 2003.

Gros, V., Bonsang, B., and Sarda Esteve, R.: Atmospheric carbon monoxide "in situ" monitoring by automatic gas chromatography, Chemosphere - Global Change Science, 1, 153-161, 1999.

Haeffelin, M., Barthès, L., Bock, O., Boitel, C., Bony, S., Bouniol, D., Chepfer, H., Chiriaco, M., Cuesta, J., Delanoë, J., Drobinski, P., Dufresne, J.-L., Flamant, C., Grall, M., Hodzic, A., Hourdin, F., Lapouge, F., Lemaître, Y., Mathieu, A., Morille, Y., Naud, C., Noël, V., O'Hirok, W., Pelon, J., Pietras, C., Protat, A., Romand, B., Scialom, G., and Vautard, R.: SIRTA, a ground-based atmospheric observatory for cloud and aerosol research, Ann. Geophys., 23, 253-275, doi:10.5194/angeo-23-253-2005, 2005.

Haeffelin, M., Angelini, F., Morille, Y., Martucci, G., Frey, S., Gobbi, G.-P., Lolli, S., O’Dowd, C. D., Sauvage, L., XuerefRémy, I., Wastine, B., Feist, D., : Evaluation of mixing height retrievals from automatic profiling lidars and ceilometers in view of future integrated networks in Europe, Bound.-Lay. Meteorol., 143, 49-75, 2011.

Hasel, M., Kottmeier, C., Corsmeier, U., and Wieser, A.: Airborne measurements of turbulent trace gas fluxes and analysis of eddy structure in the convective boundary layer over complex terrain, Atmos. Res., 74, 381-402, 2005.

Heard, D. E. and Pilling, M. J.: Measurement of $\mathrm{OH}$ and $\mathrm{HO}_{2}$ in the troposphere, Chem. Rev., 103, 5163-5198, 2003.

Hofzumahaus, A., Rohrer, F., Lu, K. D., Bohn, B., Brauers, T., Chang, C. C., Fuchs, H., Holland, F., Kita, K., Kondo, Y., Li, X., Lou, S. R., Shao, M., Zeng, L. M., Wahner, A., and Zhang, Y. H.: Amplified Trace Gas Removal in the Troposphere, Science, 324, 1702-1704, 2009.

Holland, F., Hofzumahaus, A., Schafer, R., Kraus, A., and Patz, H. W.: Measurements of $\mathrm{OH}$ and $\mathrm{HO}_{2}$ radical concentrations and photolysis frequencies during BERLIOZ, J. Geophys. Res., 108, D4, 8246, 2003.

Jenkin, M. E., Saunders, S. M., Wagner, V., and Pilling, M. J.: Protocol for the development of the Master Chemical Mechanism, MCM v3 (Part B): tropospheric degradation of aromatic volatile organic compounds, Atmos. Chem. Phys., 3, 181-193, doi:10.5194/acp-3-181-2003, 2003.

Kanaya, Y., Matsumoto, J., Kato, S., and Akimoto, H.: Behavior of $\mathrm{OH}$ and $\mathrm{HO} 2$ radicals during the Observations at a Remote Island of Okinawa (ORION99) field campaign 2. Comparison between observations and calculations, J. Geophys. Res., 106, 24209-24223, 2001.

Kanaya, Y., Cao, R. Q., Akimoto, H., Fukuda, M., Komazaki, Y., Yokouchi, Y., Koike, M., Tanimoto, H., Takegawa, N., and Kondo, Y.: Urban photochemistry in central Tokyo: 1. Observed and modeled $\mathrm{OH}$ and $\mathrm{HO}_{2}$ radical concentrations during the winter and summer of 2004, J. Geophys. Res., 112, D21312, doi:10.1029/2007JD008670, 2007.

Kanaya, Y., Hofzumahaus, A., Dorn, H.-P., Brauers, T., Fuchs, H., Holland, F., Rohrer, F., Bohn, B., Tillmann, R., Wegener, R., Wahner, A., Kajii, Y., Miyamoto, K., Nishida, S., Watanabe, K., Yoshino, A., Kubistin, D., Martinez, M., Rudolf, M., Harder, H., Berresheim, H., Elste, T., Plass-Dülmer, C., Stange, G., Kleffmann, J., Elshorbany, Y., and Schurath, U.: Comparisons of observed and modeled $\mathrm{OH}$ and $\mathrm{HO}_{2}$ concentrations during the ambient measurement period of the HOxComp field campaign, Atmos. Chem. Phys., 12, 2567-2585, doi:10.5194/acp-12-2567- 
2012, 2012.

Kato, S., Sato, T., and Kajii, Y.: A method to estimate the contribution of unidentified VOCs to $\mathrm{OH}$ reactivity, Atmos. Environ., 45, 5531-5539, 2011.

Kleffmann, J.: Daytime sources of nitrous acid (HONO) in the atmospheric boundary layer, Chemphyschem, 8, 1137-1144, 2007.

Kleffmann, J., Gavriloaiei, T., Hofzumahaus, A., Holland, F., Koppmann, R., Rupp, L., Schlosser, E., Siese, M., and Wahner, A.: Daytime formation of nitrous acid: A major source of $\mathrm{OH}$ radicals in a forest, Geophys. Res. Lett., 32, L05818, doi:10.1029/2005GL022524, 2005.

Kukui, A., Ancellet, G., and Le Bras, G.: Chemical ionisation mass spectrometer for measurements of $\mathrm{OH}$ and Peroxy radical concentrations in moderately polluted atmospheres, J. Atmos. Chem., 61, 133-154, 2008.

Levy, H.: Photochemistry of the lower troposphere, Planet. Space Sci, 20, 919-935, 1972.

Liu, Z., Wang, Y., Gu, D., Zhao, C., Huey, L. G., Stickel, R., Liao, J., Shao, M., Zhu, T., Zeng, L., Amoroso, A., Costabile, F., Chang, C.-C., and Liu, S.-C.: Summertime photochemistry during CAREBeijing-2007: $\mathrm{RO}_{\mathrm{x}}$ budgets and $\mathrm{O}_{3}$ formation, Atmos. Chem. Phys. Discuss., 12, 4679-4717, doi:10.5194/acpd12-4679-2012, 2012

Lu, K. D., Rohrer, F., Holland, F., Fuchs, H., Bohn, B., Brauers, T., Chang, C. C., Häseler, R., Hu, M., Kita, K., Kondo, Y., Li, X., Lou, S. R., Nehr, S., Shao, M., Zeng, L. M., Wahner, A., Zhang, Y. H., and Hofzumahaus, A.: Observation and modelling of $\mathrm{OH}$ and $\mathrm{HO}_{2}$ concentrations in the Pearl River Delta 2006: a missing $\mathrm{OH}$ source in a VOC rich atmosphere, Atmos. Chem. Phys., 12, 1541-1569, 2012, http://www.atmos-chem-phys.net/12/1541/2012/.

Madronich, S., McKenzie, R. L., Bjorn, L. O., and Caldwell, M. M.: Changes in biologically active ultraviolet radiation reaching the Earth's surface, J. Photoch. Photobio. A, 46, 5-19, 1998.

Mao, J., Ren, X., Zhang, L., Van Duin, D. M., Cohen, R. C., Park, J.-H., Goldstein, A. H., Paulot, F., Beaver, M. R., Crounse, J. D., Wennberg, P. O., DiGangi, J. P., Henry, S. B., Keutsch, F. N., Park, C., Schade, G. W., Wolfe, G. M., Thornton, J. A., and Brune, W. H.: Insights into hydroxyl measurements and atmospheric oxidation in a California forest, Atmos. Chem. Phys., 12, 8009-8020, doi:10.5194/acp-12-8009-2012, 2012.

Martinez, M., Harder, H., Kovacs, T. A., Simpas, J. B., Bassis, J., Lesher, R., Brune, W. H., Frost, G. J., Williams, E. J., Stroud, C. A., Jobson, B. T., Roberts, J. M., Hall, S. R., Shetter, R. E., Wert, B., Fried, A., Alicke, B., Stutz, J., Young, V. L., White, A. B., and Zamora, R. J.: $\mathrm{OH}$ and $\mathrm{HO}_{2}$ concentrations, sources, and loss rates during the Southern Oxidants Study in Nashville, Tennessee, summer 1999, J. Geophys. Res., 108, D19, 4617, 2003.

McKenzie, R. L., Aucamp, P. J., Bais, A. F., Bjorn, L. O., and Ilyas, M.: Changes in biologically-active ultraviolet radiation reaching the Earth's surface, Photoch. Photobio. Sci., 6, 218-231, 2007.

Mihelcic, D., Holland, F., Hofzumahaus, A., Hoppe, L., Konrad, S., Musgen, P., Patz, H. W., Schafer, H. J., Schmitz, T., VolzThomas, A., Bachmann, K., Schlomski, S., Platt, U., Geyer, A., Alicke, B., and Moortgat, G. K.: Peroxy radicals during BERLIOZ at Pabstthum: Measurements, radical budgets and ozone production, J. Geophys. Res., 108, D4, 8254, 2003.

Mount, G. H., and Williams, E. J.: An overview of the tropospheric $\mathrm{OH}$ photochemistry experiment, Fritz Peak Idaho Hill, Colorado,
Fall 1993, J. Geophys. Res., 102, 6171-6186, 1997.

Nielsen, T., Hansen, A. M., and Thomsen, E. L.: A convenient method for preparation of pure standards of peroxyacetyl nitrate for atmospheric analyses, Atmos. Environ., 16, 2447-2450, 1982.

Pietras, C., Boitel, C., Dupont, J. C., Haeffelin, M., Lapouge, F., Morille, Y., Noel, V., and Romand, B.: SIRTA, a multisensor platform for clouds and aerosols characterization in the atmosphere: infrastructure, objective and prospective - art. no. 67501A, in: Lidar Technologies, Techniques, and Measurements for Atmospheric Remote Sensing Iii, P. Soc. Photo-Opt. Inst., A7501-A7501, 2007.

Reiner, T., Hanke, M., and Arnold, F.: Atmospheric peroxy radical measurements by ion molecule reaction mass spectrometry: A novel analytical method using amplifying chemical conversion to sulfuric acid, J. Geophys. Res., 102, 1311-1326, 1997.

Ren, X. R., Harder, H., Martinez, M., Lesher, R. L., Oliger, A., Shirley, T., Adams, J., Simpas, J. B., and Brune, W. H.: HO x concentrations and $\mathrm{OH}$ reactivity observations in New York City during PMTACS-NY2001, Atmos. Environ., 37, 3627-3637, 2003a.

Ren, X. R., Harder, H., Martinez, M., Lesher, R. L., Oliger, A., Simpas, J. B., Brune, W. H., Schwab, J. J., Demerjian, K. L., He, Y., Zhou, X. L., and Gao, H. G.: OH and HO2 chemistry in the urban atmosphere of New York City, Atmos. Environ., 37, 3639-3651, $2003 b$.

Ren, X. R., Brune, W. H., Oliger, A., Metcalf, A. R., Simpas, J. B., Shirley, T., Schwab, J. J., Bai, C. H., Roychowdhury, U., Li, Y. Q., Cai, C. X., Demerjian, K. L., He, Y., Zhou, X. L., Gao, H. L., and Hou, J.: $\mathrm{OH}, \mathrm{HO}_{2}$, and $\mathrm{OH}$ reactivity during the PMTACS-NY Whiteface Mountain 2002 campaign: Observations and model comparison, J. Geophys. Res., 111, D10S03, doi:10.1029/2005JD006126, 2006.

Ren, X. R., Olson, J. R., Crawford, J. H., Brune, W. H., Mao, J. Q. Long, R. B., Chen, Z., Chen, G., Avery, M. A., Sachse, G. W., Barrick, J. D., Diskin, G. S., Huey, L. G., Fried, A., Cohen, R. C., Heikes, B., Wennberg, P. O., Singh, H. B., Blake, D. R., and Shetter, R. E.: HO(x) chemistry during INTEX-A 2004: Observation, model calculation, and comparison with previous studies, J. Geophys. Res., 113, D05310, doi:10.1029/2007JD009166, 2008.

Salisbury, G., Rickard, A. R., Monks, P. S., Allan, B. J., Bauguitte, S., Penkett, S. A., Carslaw, N., Lewis, A. C., Creasey, D. J. Heard, D. E., Jacobs, P. J., and Lee, J. D.: Production of peroxy radicals at night via reactions of ozone and the nitrate radical in the marine boundary layer, J. Geophys. Res.-Atmos., 106 , 12669-12687, doi:10.1029/2000jd900754, 2001.

Saunders, S. M., Jenkin, M. E., Derwent, R. G., and Pilling, M. J.: World Wide Web site of a Master Chemical Mechanism (MCM) for use in tropospheric chemistry models, Atmos. Environ., 31, 1249-1249, 1997.

Saunders, S. M., Jenkin, M. E., Derwent, R. G., and Pilling, M. J.: Protocol for the development of the Master Chemical Mechanism, MCM v3 (Part A): tropospheric degradation of nonaromatic volatile organic compounds, Atmos. Chem. Phys., 3, 161-180, doi:10.5194/acp-3-161-2003, 2003.

Shirley, T. R., Brune, W. H., Ren, X., Mao, J., Lesher, R., Cardenas, B., Volkamer, R., Molina, L. T., Molina, M. J., Lamb, B., Velasco, E., Jobson, T., and Alexander, M.: Atmospheric oxidation in the Mexico City Metropolitan Area (MCMA) during April 2003, Atmos. Chem. Phys., 6, 2753-2765, doi:10.5194/acp-6- 
2753-2006, 2006.

Smith, S. C., Lee, J. D., Bloss, W. J., Johnson, G. P., Ingham, T., and Heard, D. E.: Concentrations of $\mathrm{OH}$ and $\mathrm{HO}_{2}$ radicals during NAMBLEX: measurements and steady state analysis, Atmos. Chem. Phys., 6, 1435-1453, doi:10.5194/acp-6-1435-2006, 2006.

Sommariva, R., Bloss, W. J., Brough, N., Carslaw, N., Flynn, M., Haggerstone, A.-L., Heard, D. E., Hopkins, J. R., Lee, J. D., Lewis, A. C., McFiggans, G., Monks, P. S., Penkett, S. A., Pilling, M. J., Plane, J. M. C., Read, K. A., Saiz-Lopez, A., Rickard, A. R., and Williams, P. I.: $\mathrm{OH}$ and $\mathrm{HO}_{2}$ chemistry during NAMBLEX: roles of oxygenates, halogen oxides and heterogeneous uptake, Atmos. Chem. Phys., 6, 1135-1153, doi:10.5194/acp-6-1135-2006, 2006.

Stockwell, W. R., Kirchner, F., Kuhn, M., and Seefeld, S.: A new mechanism for regional atmospheric chemistry modeling, J. Geophys. Res., 102, 25847-25879, 1997.

Stohl, A., Forster, C., Frank, A., Seibert, P., and Wotawa, G.: Technical note: The Lagrangian particle dispersion model FLEXPART version 6.2, Atmos. Chem. Phys., 5, 2461-2474, doi:10.5194/acp-5-2461-2005, 2005.

Tan, D., Faloona, I., Simpas, J. B., Brune, W., Shepson, P. B., Couch, T. L., Sumner, A. L., Carroll, M. A., Thornberry, T., Apel, E., Riemer, D., and Stockwell, W.: $\mathrm{HO}_{x}$ budgets in a deciduous forest: Results from the PROPHET summer 1998 campaign, J. Geophys. Res., 106, 24407-24427, 2001.
Tanner, D. J., Jefferson, A., and Eisele, F. L.: Selected ion chemical ionization mass spectrometric measurement of $\mathrm{OH}, \mathrm{J}$. Geophys. Res., 102, 6415-6425, 1997.

Verwer, J. G. and Vanloon, M.: An Evaluation of Explicit PseudoSteady-State Approximation Schemes for Stiff Ode Systems from Chemical-Kinetics, J. Comput. Phys., 113, 347-352, 1994.

Verwer, J. G., Blom, J. G., VanLoon, M., and Spee, E. J.: A comparison of stiff ODE solvers for atmospheric chemistry problems, Atmos. Environ., 30, 49-58, 1996.

Volkamer, R., Sheehy, P., Molina, L. T., and Molina, M. J.: Oxidative capacity of the Mexico City atmosphere - Part 1: A radical source perspective, Atmos. Chem. Phys., 10, 6969-6991, doi:10.5194/acp-10-6969-2010, 2010.

Wang, J., Doussin, J. F., Perrier, S., Perraudin, E., Katrib, Y., Pangui, E., and Picquet-Varrault, B.: Design of a new multi-phase experimental simulation chamber for atmospheric photosmog, aerosol and cloud chemistry research, Atmos. Meas. Tech., 4, 2465-2494, doi:10.5194/amt-4-2465-2011, 2011.

Webb, R., Stromberg, I. M., Li, H., and Barttlett, L. M.: Airborne spectral measurements of surface reflectivity at ultraviolet and visible wavelengths, J. Geophys. Res., 105, 4945-4948, 2000. 